\title{
In-situ surface and gas phase analysis for kinetic studies under transient conditions The catalytic hydrogenation of $\mathrm{CO}_{2}$
}

\author{
Michel Marwood, Ralf Doepper, Albert Renken * \\ Swiss Federal Institute of Technology 1015, Lausanne, Switzerland
}

\begin{abstract}
Transient measurement techniques are applied for the kinetic investigation of the reaction mechanism of the carbon dioxide methanation, using diffuse reflectance infrared spectroscopy and mass spectrometry. The coupled information of the surface intermediates and the gas phase components time evolution leads to accurate identification of spectator species on the surface. Reaction intermediates, carbon monoxide and formates have been identified. The former is a key intermediate, and its hydrogenation leads to methane formation. The latter is fixed on the support, in equilibrium with a active formate species on the interface metal-support. A reaction mechanism is proposed including the formation step of the formates through a carbonate species.
\end{abstract}

Keywords: Carbon dioxide methanation; Kinetics; Transient measurement

\section{Introduction}

The transient behavior of heterogeneous catalyzed reactions is strongly influenced by the elementary step rate constants [1]. Therefore, dynamic experiments can be used in order to distinguish between different models describing the steady-state behavior, or to investigate elementary steps for the determination of reaction mechanisms. Studies with simultaneous surface and gas phase measurements considerably increase the amount of information available for the establishment of a kinetic model. Yet it is important to distinguish reactive adsorbed species from spectator surface species that do not participate in the reaction [2].

Transient experiments can be used as a tool to understand the role of the

\footnotetext{
${ }^{*}$ Corresponding author. 
observed species. By exposing the catalyst to concentration variations and following the time evolution of the adsorbed species under various conditions, one can conclude on the reactivity of the observed surface species. Basically, this type of experimentation may be classified into step-down and step-up transients. The former consists in switching off the reactants, or some of them, and following the removal of the adsorbed species with time. The latter having exactly the inverse procedure, and one can follow the formation of the intermediates starting with different initial states.

The demonstration of those experimental techniques is shown for the mechanistic investigation of the carbon dioxide methanation on a $\mathrm{Ru} / \mathrm{TiO}_{2}$ catalyst at $383 \mathrm{~K}$, giving a particular interest to the role of the adsorbed formates. Surface species are investigated by means of diffuse-reflectance infrared-spectroscopy using Fourier-transforms (DRIFTS) and gas-phase components by mass-spectrometry.

The main features about this reaction are summarized by Henderson and Worley [3]. $\mathrm{CO}_{2}$ hydrogenation is much more selective for $\mathrm{CH}_{4}$ than $\mathrm{CO}$ hydrogenation. Higher selectivities, higher reaction rates and lower reaction temperatures are thought to result from favorable distribution of adsorbed $\mathrm{CO}$, $(\mathrm{CO})_{\mathrm{a}}$, and adsorbed carbon species during $\mathrm{CO}_{2}$ methanation compared to $\mathrm{CO}$ methanation. Adsorbed formate species are observed by infrared spectroscopy and appear to be mainly on the support. Furthermore, $(\mathrm{CO})_{\mathrm{a}}$ was detected and identified as a major metal-adsorbed intermediate ([3,4] and [5]). At $383 \mathrm{~K}$, on a $\mathrm{Ru} / \mathrm{TiO}_{2}$ catalyst, the $\mathrm{CO}_{2}$ steady-state methanation rate can be described by a simple power law where the reaction rate is almost of order $1 / 2$ in hydrogen concentration and is inhibited by the reaction product water [6].

\section{Experimental}

The experimental set-up consisted of a controlled-environment diffuse-reflectance infra-red (DRIFT) cell. A schematic representation is given by Marwood et al. [7]. Approximately $0.06-0.08 \mathrm{~g}$ of the sample was placed in the sample holder of the DRIFTS cell. This resulted in very small methane conversions $(<0.5 \%)$ for the carbon dioxide methanation reaction under the experimental conditions studied and therefore the DRIFTS cell was considered to be a differential reactor. The partial pressure of water in the feed was controlled by a water evaporator placed at the entrance of the cell. Feed was supplied through one of two banks of mass flow controllers that could be selected using a low-volume, four-way switching valve across which pressure and flow rate were equilibrated to avoid surges during switching.

Reactor effluent composition was determined with a Balzers QMG 420 quadrupole mass spectrometer coupled with a two-stage continuous atmospheric sampling system. The DRIFTS cell (Harrick HVC-DRP vacuum chamber with 
DRA-2CO diffuse reflectance accessory) was located in a Nicolet 710 FTIR spectrometer equipped with a mid range MCT detector and a $\mathrm{KBr}$ beamsplitter. The instrument was operated at a scan speed of $1 \mathrm{scan} / \mathrm{s}$, a resolution of $4 \mathrm{~cm}^{-1}$ and a number of 10 to 40 interferograms were co-added depending on the time interval between each spectrum collection.

To increase the conversion, and therefore to get a more precise measure of the gas phase concentrations evolution during transients, a loop containing a fixed bed was added to the DRIFTS device. The whole set-up, formed by the fixed bed and the infrared cell is described by Marwood et al. [6], and is called afterwards recycle reactor. $4 \mathrm{~g}$ of catalyst were placed in the fixed bed while 0.06-0.08 g were placed in the DRIFTS cell. Both catalyst charges were heated to the same temperature. The recycle reactor was operated at a recycle ratio of 40-60. This resulted in maximal conversion per passage in the fixed-bed of $0.075 \%$ at $383 \mathrm{~K}$ and $0.5 \%$ at $435 \mathrm{~K}$ under the operating conditions studied. Therefore the concentrations in the fixed-bed, at the exit of the fixed-bed and at the entrance to the DRIFTS cell were considered to be identical. There are no mass transfer limitations in the DRIFTS cell where the flow rate is the smallest [8]. As a consequence the DRIFTS cell could be considered as a window into the reactor, giving a representative view of the entire catalyst surface under the reaction conditions. In addition, the contribution to the total conversion of the small catalytic charge placed in the DRIFTS cell can be assumed to be negligible. Hence gas phase measurements were realized in a well characterized hydrodynamic system.

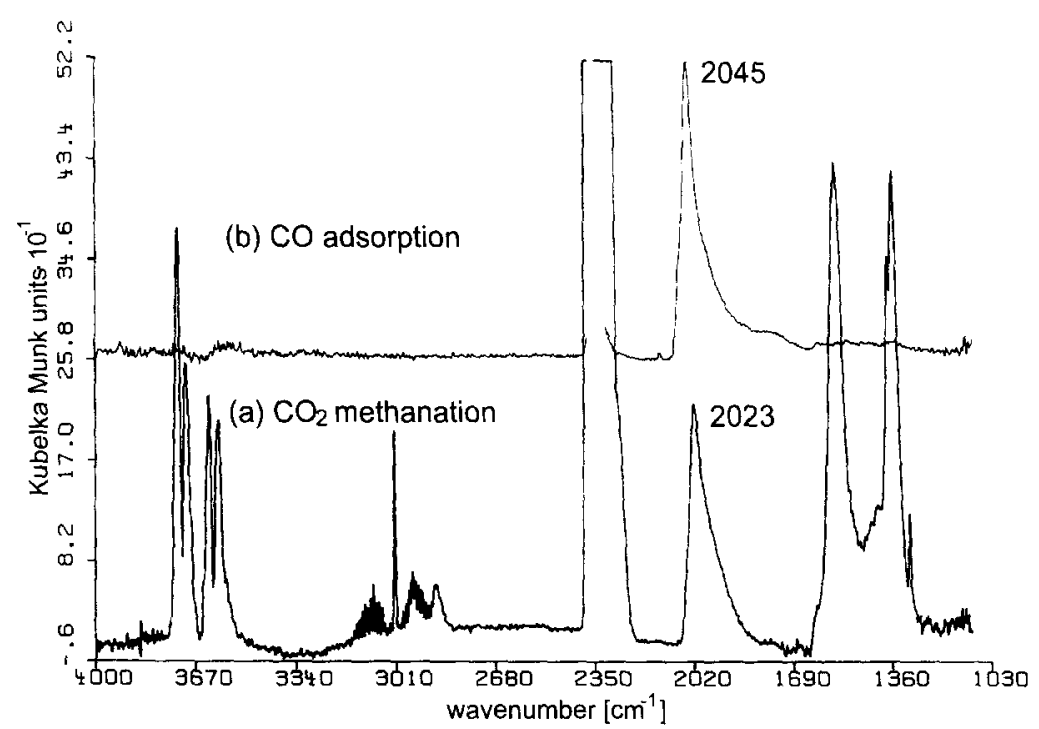

Fig. 1. (a) DRIFTS spectrum for $2 \% \mathrm{Ru} / \mathrm{TiO}_{2}$ during the steady-state carbon dioxide methanation reaction at $383 \mathrm{~K}$; (b) adsorption of carbon monoxide: DRIFTS spectrum for $2 \% \mathrm{Ru} / \mathrm{TiO}_{2}$ in $100 \% \mathrm{He}$ at $383 \mathrm{~K}$ after exposure for $10 \mathrm{~min}$ to $40 \% \mathrm{CO}$ in $\mathrm{He}$; DRIFTS-recycle-reactor, $10 \% \mathrm{CO}_{2}$ and $40 \% \mathrm{H}_{2}, \mathrm{He}$ carrier, $P_{\mathrm{H}_{2} \mathrm{O}}=0.8 \mathrm{mbar}$, feed $=50 \mathrm{Nml} / \mathrm{min}$, total pressure $=1.2 \mathrm{bar}$, recycle ratio $=40$; DRIFTS-recycle-reactor. 


\subsection{Identification of adsorbed species}

Fig. 1a shows the DRIFTS spectrum obtained for the surface of the $2 \%$ $\mathrm{Ru} / \mathrm{TiO}_{2}$ catalyst during the steady-state carbon dioxide methanation reaction at $383 \mathrm{~K}$. The $2023 \mathrm{~cm}^{-1}$ band measured for the $2 \% \mathrm{Ru} / \mathrm{TiO}_{2}$ catalyst during the carbon dioxide methanation reaction is assigned to linearly bound adsorbed carbon monoxide, abbreviated $(\mathrm{CO})_{\mathrm{a}}$, even though a $17 \mathrm{~cm}^{-1}$ difference in frequency is observed when comparing it with the band formed from the adsorption of carbon monoxide (Fig. 1b). This latter band at $2045 \mathrm{~cm}^{-1}$ is characteristic of linearly bound carbon monoxide on $\mathrm{Ru}^{0}$ for a carbon monoxide surface coverage $\theta_{\mathrm{CO}}=1$ (e.g., [9] and [10]). A coverage effect (e.g., [11]) and/or a co-adsorption effect of hydrogen (e.g., [5] and [12]) is responsible for such a $17 \mathrm{~cm}^{-1}$ frequency shift. Carbon monoxide band frequencies between 2035 and $1990 \mathrm{~cm}^{-1}$ are reported in the literature for supported ruthenium catalysts exposed to carbon dioxide and hydrogen (e.g., [5,13-15] and [16]). A weak infrared band located at $2119 \mathrm{~cm}^{-1}$ is observed after exposure of the titania surface to a flow of carbon monoxide. This band disappears rapidly in a $100 \%$ helium stream.

Fig. $2 \mathrm{~b}$ shows the infrared bands $\left(1361,1379,1556,2878\right.$ and $\left.2953 \mathrm{~cm}^{-1}\right)$ measured for the $2 \% \mathrm{Ru} / \mathrm{TiO}_{2}$ catalyst during the carbon dioxide methanation reaction at $383 \mathrm{~K}$. These bands are almost identical to the ones observed in Fig. 2a recorded for the titania P25 surface exposed to $2 \mu 1$ of formic acid injected into the helium carrier at $383 \mathrm{~K}$. The bands at $1361 \mathrm{~cm}^{-1}$ (symmetric $\mathrm{O}-\mathrm{C}-\mathrm{O}$

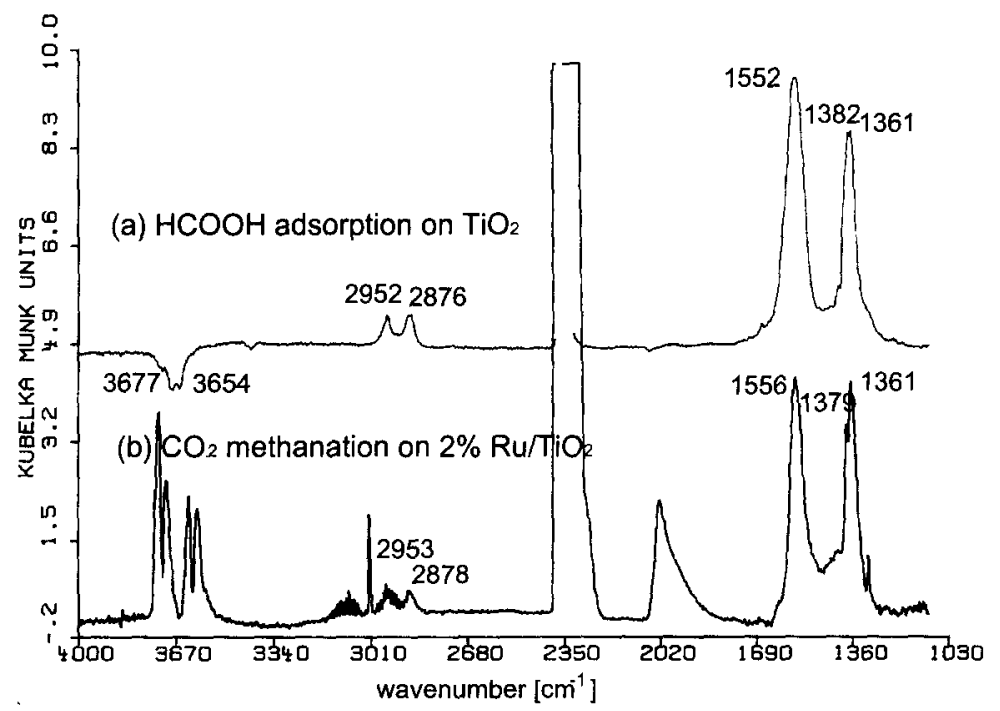

Fig. 2. (a) Adsorption of formic acid: DRIFTS spectrum for a titania sample in $100 \% \mathrm{He}$ at $383 \mathrm{~K}$ after the injection of $0.1 \mu \mathrm{l}$ of $\mathrm{HCOOH}$; DRIFTS-reactor; $P_{\mathrm{H}_{2} \mathrm{O}}=0.8 \mathrm{mbar}$, feed $=50 \mathrm{Nml} / \mathrm{min}$, total pressure $=1.2$ bar. (b) DRIFTS spectrum for $2 \% \mathrm{Ru} / \mathrm{TiO}_{2}$ during the steady-state carbon dioxide methanation reaction at $383 \mathrm{~K}$; DRIFTS-recycle-reactor, $10 \% \mathrm{CO}_{2}$ and $40 \% \mathrm{H}_{2}$, He carrier, recycle ratio $=40$. 
stretching, $\left.v_{\mathrm{s}}\right), 1382 \mathrm{~cm}^{-1}\left(\mathrm{C}-\mathrm{H}\right.$ bending), $1552 \mathrm{~cm}^{-1}$ (asymmetric $\mathrm{O}-\mathrm{C}-\mathrm{O}$ stretching $v_{\mathrm{as}}$ ), $2876 \mathrm{~cm}^{-1}$ (C-H stretching) and $2952 \mathrm{~cm}^{-1}$ (combination of the asymmetric $\mathrm{O}-\mathrm{C}-\mathrm{O}$ stretching and $\mathrm{C}-\mathrm{H}$ bending) of Fig. $2 \mathrm{~b}$ are assigned to the stretching and bending vibrations of a dissociated formic acid molecule adsorbed on the titania surface. The wavenumbers measured are similar to those reported by Busca et al. [17] for the formate ion formed by the room temperature adsorption of formaldehyde on the titania P25 surface. By comparison the bands observed in Fig. 2a are assigned to a formate species, $\left(\mathrm{HCOO}^{-}\right)_{\mathrm{a}}$, adsorbed on the $2 \% \mathrm{Ru} / \mathrm{TiO}_{2}$ catalyst surface. Information on the structure of this species can be deduced from the value of $\Delta v=v_{\mathrm{as}}-\boldsymbol{v}_{\mathrm{s}}$. Shido et al. [18] report that when $\Delta v$ is larger or smaller than that of a free ion, the formate is considered to be respectively unidentate or bidentate. When $\Delta v$ is as large as that of a free ion, it is assigned the bridge-type structure. A bidentate structure is deduced from the $\Delta v=195 \mathrm{~cm}^{-1}$ value calculated for the formate ion adsorbed on the $2 \% \mathrm{Ru} / \mathrm{TiO}_{2}$ surface.

A series of infrared bands, attributed to carbonate, $\left(\mathrm{CO}_{3}^{2-}\right)_{\mathrm{a}}$, and hydrogen carbonate species, $\left(\mathrm{HCO}_{3}^{-}\right)_{\mathrm{a}}$, are observed in the spectra recorded at $383 \mathrm{~K}$ on the $2 \% \mathrm{Ru} / \mathrm{TiO}_{2}$ exposed to $\mathrm{CO}_{2}$ or on the titania $\mathrm{P} 25$ support material exposed to the reaction mixture. Similar bands are reported in the literature for such species formed on titania by the room temperature adsorption of carbon dioxide (e.g., [19] and [20]). Unidentate carbonate (1550 and $1356 \mathrm{~cm}^{-1}$ ), hydrogen carbonate $\left(1550,1425,1220 \mathrm{~cm}^{-1}\right)$ and bidentate carbonate $\left(1670,1243 \mathrm{~cm}^{-1}\right)$ structures are assigned to the peaks observed in Fig. 2a and b. These species are also adsorbed on the $2 \% \mathrm{Ru} / \mathrm{TiO}_{2}$ catalyst surface during the carbon dioxide methanation, as is shown in Fig. $2 \mathrm{c}$ by the presence of the 1670 and $1450 \mathrm{~cm}^{-1}$ bands. The infrared bands characteristic of the carbonate and hydrogen carbonate are partially hidden by the more intense bands of the formate ion. This overlap must be taken into account when considering the $v_{\text {as }}$ and $v_{\mathrm{s}}$ vibrations of the formate ion. The formate data will be, when possible, represented by the area of its $\mathrm{C}-\mathrm{H}$ bending vibration $\left(2895-2810 \mathrm{~cm}^{-1}\right)$, abbreviated $\mathrm{vib}_{\mathrm{C}-\mathrm{H}}$, as this band is unaffected by other oxygenated compounds. But this band has a poor signal/noise ratio and for the majority of the experiments, this ratio is unacceptably low. In these situations, the formate data is represented by the height of the $1360 \mathrm{~cm}^{-1}$ symmetric $\mathrm{O}-\mathrm{C}-\mathrm{O}$ peak, abbreviated $\mathrm{vib}_{\mathrm{O}-\mathrm{C}-\mathrm{O}}$, knowing that this value corresponds in fact to the sum of the unidentate carbonate and formate vibrations.

\section{Results and discussion}

\subsection{Adsorbed carbon monoxide}

The stability and reactivity of $(\mathrm{CO})_{\mathrm{a}}$ at $383 \mathrm{~K}$ is shown in Fig. 3 by the transient response of the $(\mathrm{CO})_{\mathrm{a}}$ band integral, abbreviated $\mathrm{vib}_{\mathrm{C}=\mathrm{O}}$, and $\mathrm{CH}_{4}$ 


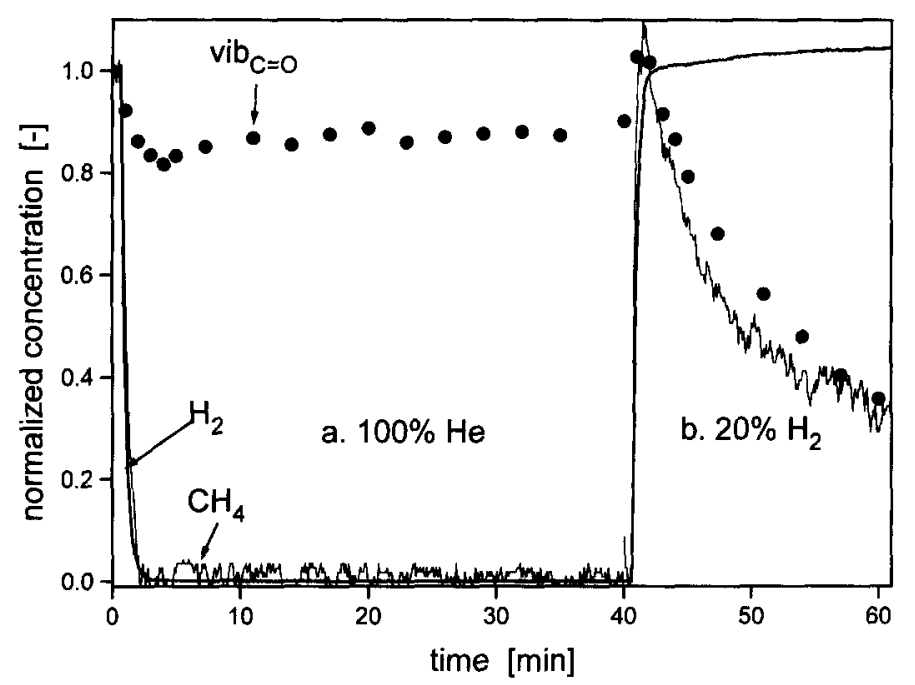

Fig. 3. Transient behavior of the normalized $\mathrm{vib}_{\mathrm{C}}=\mathrm{o}, \mathrm{H}_{2}$ and $\mathrm{CH}_{4}$ values for $2 \% \mathrm{Ru} / \mathrm{TiO}_{2}$ at $383 \mathrm{~K}$ after switching from $10 \% \mathrm{CO}_{2}$ and $20 \% \mathrm{H}_{2}$ in $\mathrm{He}$ to: (a) $100 \% \mathrm{He}$, (b) $20 \% \mathrm{H}_{2}$ following (a); $P_{\mathrm{H}_{2} \mathrm{O}}=2.6 \mathrm{mbar}$; DRIFTS-reactor.

concentration measured during a step change in composition from the reaction mixture to $100 \%$ helium in the DRIFTS-reactor. An immediate decrease of the methane concentration is observed during the first $3 \mathrm{~min}$ of the experiment as the hydrogen concentration falls to zero. A $20 \%$ decrease of the $v^{2} b_{C=O}$ value is also observed. This latter is attributed to an artifact (hydrogen influences the position of the baseline and the signal intensity), rather than to an actual modification of the $(\mathrm{CO})_{\mathrm{a}}$ surface coverage, based on the observation, at $t=40$ min, of an immediate recovery of the initial $v^{2} b_{C=0}$ value as hydrogen is reintroduced in the system. Taking this artifact into account, the $(\mathrm{CO})_{\mathrm{a}}$ surface coverage is not modified by the 40-min He purge. A sharp methane production is observed at $t=40 \mathrm{~min}$, when the feed is subsequently switched to $20 \% \mathrm{H}_{2}$. As there are no gaseous carbon sources, methane must be formed from the hydrogenation of surface adsorbed carbonaceous intermediates. The simultaneous observation of a decrease of the $\mathrm{vib}_{\mathrm{C}}=\mathrm{O}$ value demonstrates that adsorbed carbon monoxide is reactive in hydrogen and that methane is formed as the result of the hydrogenation of this species.

Under steady-state conditions, the $(\mathrm{CO})_{\mathrm{a}}$ concentration is the balance between the formation on one side, and the desorption and the hydrogenation on the other side. To distinguish these three reactions, temperature programmed desorption under well defined atmospheres have been performed (Fig. 4). The relative reactivity of $(\mathrm{CO})_{\mathrm{a}}$ in $100 \% \mathrm{He}$ or in hydrogen at $383 \mathrm{~K}$ is further shown in this figure. As the $\mathrm{CO}$ concentration in the gas phase is very low during the desorption experiments, readsorption can be neglected, and a simple model of desorption, hydrogenation and reaction is established to describe these experi- 


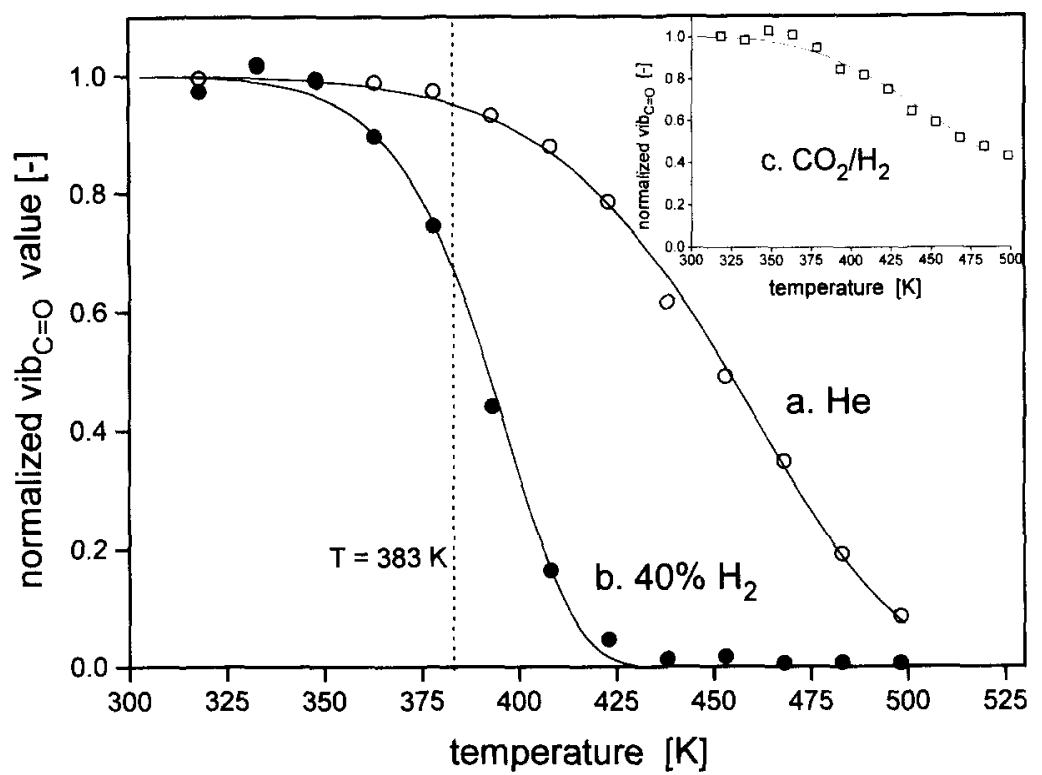

Fig. 4. Transient behavior of the normalized vib $_{\mathrm{C}=\mathrm{O}}$ value for $2 \% \mathrm{Ru} / \mathrm{TiO}_{2}$ in (a) $\mathrm{He},(\mathrm{b}) 40 \% \mathrm{H}_{2}$ and (c) $10 \% \mathrm{CO}_{2}+40 \% \mathrm{H}_{2}$ in $\mathrm{He}$ feed, under a $3 \mathrm{~K} /$ min programmed temperature ramp starting at $303 \mathrm{~K}$ : $P_{\mathrm{H}, \mathrm{O}}=1.4$ mbar. Surface $(\mathrm{CO})_{\mathrm{a}}$ was initially formed by exposing the catalyst to $10 \% \mathrm{CO}_{2}$ and $40 \% \mathrm{H}_{2}$ in $\mathrm{He}$ at $383 \mathrm{~K}$ for $45 \mathrm{~min}$. The feed was then switched to the (a), (b) or (c) compositions and the temperature was decreased to $303 \mathrm{~K}$ in $10 \mathrm{~min}$; solid lines represent a simulation of the three experiments according to Eq. (5) and with the parameters of Table 4; DRIFTS-reactor.

ments, where the $(\mathrm{CO})_{\mathrm{a}}$ formation rate is assumed proportional to the available free sites. If pore diffusion or readsorption in the pores is neglected, the mass balance for the surface coverage of the carbon monoxide species can than be written:

$$
\frac{\mathrm{d} \theta}{\mathrm{d} t}=r_{\text {desorption }}+r_{\text {hydrogenation }}+r_{\text {formation }}\left\{\begin{array}{l}
r_{\text {desorption }}=-k_{1} \theta \\
r_{\text {hydrogenation }}=-k_{2} \theta \\
r_{\text {formation }}=+k_{3}(1-\theta)
\end{array}\right.
$$

During temperature programmed desorption or reaction experiments, the time dependence of the variate temperature and $(\mathrm{CO})_{\mathrm{a}}$ surface coverage becomes

$$
\begin{aligned}
& \frac{\mathrm{d} T}{\mathrm{~d} t}=a \text { where } a=\text { ramp rate } \\
& \frac{\mathrm{d} \theta}{\mathrm{d} t}=a \frac{\mathrm{d} \theta}{\mathrm{d} T}=-k_{1} \theta-k_{2} \theta+k_{3}(1-\theta) \\
& \text { with } k_{n}=k_{n}^{383 \mathrm{~K}} \exp \left(\frac{E_{n}}{R}\left(\frac{1}{383}-\frac{1}{T}\right)\right)
\end{aligned}
$$

The model parameters were determined in three independent experiments. Desorption is the only process implicated in the temperature programmed 
experiment performed in $100 \%$ helium. Therefore $k_{1}^{383 \mathrm{~K}}$ and $E_{1}$ values can be found in order to model this experiment. These two parameters being known, $k_{2}^{383 \mathrm{~K}}$ and $E_{2}$ are added to the mass balance in order to simulate the experiment performed in $40 \% \mathrm{H}_{2}$. Finally the experiment in $\mathrm{CO}_{2} / \mathrm{H}_{2}$ is calculated by adding the formation term to the reaction set. The parameters corresponding to these three simulations are presented in Table 1 . The $k_{n}^{383 \mathrm{~K}}$ values are lumped parameters, as they depend on the initial surface concentrations and on the hydrogen and water partial pressures.

The activation energy $E_{1}=47 \mathrm{~kJ} / \mathrm{mol}$ obtained for desorption is smaller than values reported in the literature for the desorption of carbon monoxide formed from the adsorption of gaseous carbon monoxide on ruthenium. The literature values range between 96 and $155 \mathrm{~kJ} / \mathrm{mol}$ for well defined $\mathrm{Ru}$ surfaces (e.g., $\mathrm{Ru}(101)$ [21], $\mathrm{Ru}$ (001) [22], $\mathrm{Ru}(110)$ [23] and $\mathrm{Ru}(001)$ [24]). The activation energy $E_{2}=75 \mathrm{~kJ} / \mathrm{mol}$ obtained from the temperature programmed experiment in $40 \%$ hydrogen is comparable with data found in literature. For example, Cant and Bell [9] measured by in situ infrared spectroscopy a value of $80 \mathrm{~kJ} / \mathrm{mol}$ for carbon monoxide removal in hydrogen on a $4.3 \% \mathrm{Ru} / \mathrm{SiO}_{2}$ catalyst. Solymosi et al. [25] present values for carbon monoxide hydrogenation on supported $\mathrm{Rh}$ catalysts. Values ranging from 76 to $100 \mathrm{~kJ} / \mathrm{mol}$ are reported depending on the support material $\left(\mathrm{TiO}_{2}, \mathrm{SiO}_{2}, \mathrm{MgO}\right.$ and $\left.\mathrm{Al}_{2} \mathrm{O}_{3}\right)$. Mori et al. [26] measure an activation energy of $79.5 \mathrm{~kJ} / \mathrm{mol}$ for the hydrogenation of adsorbed carbon monoxide in flowing hydrogen on a $20 \% \mathrm{Ni} / \mathrm{SiO}_{2}$ catalyst.

As the gaseous carbon source is cut off, the hydrogenation of adsorbed carbon monoxide can be studied without the complication of its continuous formation. Fig. 5 shows the transient progression of $(\mathrm{CO})_{\mathrm{a}}$ during a step-change in composition from the reaction mixture to hydrogen. The uppermost spectrum is recorded during a steady-state operation just before the switch. Spectra are then acquired at 3-min intervals in various molar fractions of hydrogen in helium. Interesting trends concerning the carbon monoxide band shapes are observed. In $50 \%$ hydrogen, $(\mathrm{CO})_{\mathrm{a}}$ bands retain their original shape throughout the experiment, shifting to the lower $2016 \mathrm{~cm}^{-1}$ frequency value as coverage decreases. In $5 \%$ hydrogen, the $(\mathrm{CO})_{\mathrm{a}}$ band immediately broadens and moves to lower wave numbers. At low coverage, the principal band is centered at 1992 $\mathrm{cm}^{-1}$. In the intermediate hydrogen concentration of $20 \%$, two distinct infrared bands at 2016 and $1992 \mathrm{~cm}^{-1}$ appear at low (CO) a coverage.

Table 1

Model parameters

\begin{tabular}{lll}
\hline$n$ & $E_{n}(\mathrm{~kJ} / \mathrm{mol})$ & $k_{n}^{383 \mathrm{~K}}\left(\mathrm{~s}^{-1}\right)$ \\
\hline 1 (desorption) & 47 & $11.5 \cdot 10^{-3}$ \\
2 (hydrogenation) & 75 & $1.50 \cdot 10^{-3}$ \\
3 (formation) & 37 & $0.11 \cdot 10^{-3}$ \\
\hline
\end{tabular}



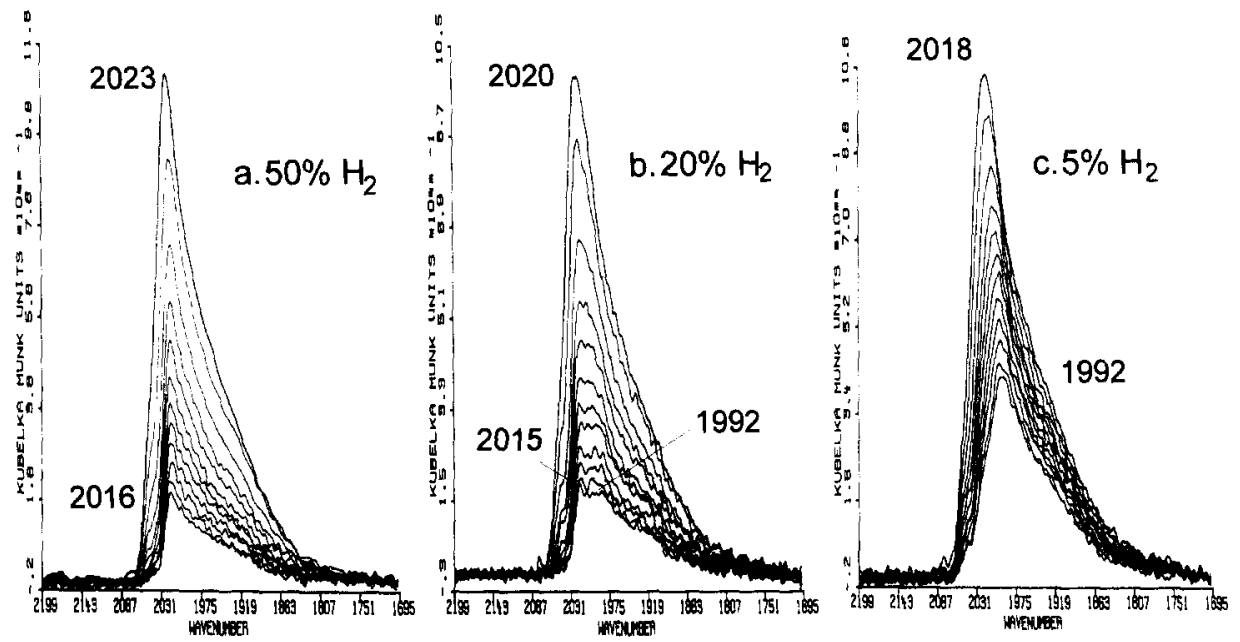

Fig. 5. DRIFTS spectra of $(\mathrm{CO})_{\mathrm{a}}$ on $2 \% \mathrm{Ru} / \mathrm{TiO}_{2}$ during transient step-down experiments. The spectra presented are recorded at $3 \mathrm{~min}$ intervals after a switch from an initial composition of $10 \% \mathrm{CO}_{2}$ and $20 \% \mathrm{H}_{2}$ in $\mathrm{He}$ to (a) $50 \% \mathrm{H}_{2}$, (b) $20 \% \mathrm{H}_{2}$ and (c) $5 \% \mathrm{H}_{2}$ in $\mathrm{He}$ at $383 \mathrm{~K}$ and $P_{\mathrm{H}_{2} \mathrm{O}}=2.4 \mathrm{mbar}$. The uppermost spectrum was recorded at steady-state in the $\mathrm{CO}_{2} / \mathrm{H}_{2}$ mixture prior to the switch; DRIFTS-reactor.

Similar observations are made in a constant $20 \%$ hydrogen stream when the water partial pressure is varied. A splitting of the original $2018 \mathrm{~cm}^{-1}$ band is observed at low coverage when the water partial pressure is increased.

It is proposed that these observations reflect the existence of ordered islands on the ruthenium surface and the subsequent destruction of these structures as $(\mathrm{CO})_{\mathrm{a}}$ coverage decreases. Hoffmann [27] reviewed the phenomena associated with islanding. It appears that

(a) a decrease of the infrared band width is observed during the destruction of the surface order. The reason for this lies in a homogeneous distribution of molecules with respect to adsite and intermolecular distances;

(b) plateaus are observed in a frequency vs. coverage plot; their information is derived from the fact that during the island formation the coverage increase occurs by adding new molecules at the border of the islands, thus keeping the intermolecular distance, and with it the frequency, largely constant;

(c) a $20 \mathrm{~cm}^{-1}$ splitting of the $(\mathrm{CO})_{\mathrm{a}}$ band is observed in certain experiments. The low frequency band is ascribed to the 'disordered' phase, where the molecules remain at approximately constant intermolecular spacing.

A comparatively small frequency shift and bandwidth is observed in Fig. 5 for the experiment in $50 \%$ hydrogen. It is proposed that an ordered structure exists during the methanation reaction and that this order is maintained as coverage is decreased. Similarly the observation of a peak broadening as well as the appearance of a low frequency infrared band in the experiments in $20 \%$ and $5 \%$ hydrogen tend to show that the ordered structure is broken as coverage is decreased in these hydrogen concentrations. The second peak corresponds then 
Table 2

Comparison of $R_{\text {CO }}$ for a 0.51 surface coverage with the steady-state rate, $R_{\mathrm{CH}_{4}}$

\begin{tabular}{rlll}
\hline$P_{\mathrm{H}_{2}}$ mbar & $k^{\prime}\left(\mathrm{s}^{-1}\right)$ & $R_{\mathrm{CO}}\left(\mu \mathrm{mol} / \mathrm{g}_{\mathrm{RuS}}\right)$ & $R_{\mathrm{CH}_{4}}\left(\mu \mathrm{mol} / \mathrm{g}_{\mathrm{RuS}}\right)$ \\
\hline 24 & $18.4 \cdot 10^{-3}$ & 0.20 & 0.26 \\
60 & $40.0 \cdot 10^{-3}$ & 0.44 & 0.43 \\
120 & $58.3 \cdot 10^{-3}$ & 0.65 & 0.64 \\
240 & $78.3 \cdot 10^{-3}$ & 0.87 & 0.95 \\
600 & $111.7 \cdot 10^{-3}$ & 1.24 & 1.61 \\
\hline
\end{tabular}

to $(\mathrm{CO})_{a}$ in the 'disordered phase'. The same correlation can be made for the effect of water. The presence of water has the effect of breaking the ordered structures as coverage is decreased. Therefore islands of $(\mathrm{CO})_{\mathrm{a}}$ exist on the ruthenium surface during the carbon dioxide methanation reaction. These ordered structures are stabilized by hydrogen and destroyed by water during the transient hydrogenation experiments.

It has been shown previously [7] that within a certain hydrogen and water concentration range (5-20\% $\mathrm{H}_{2}$ and $P_{\mathrm{H}_{2} \mathrm{O}}=2.6-12.3 \mathrm{mbar}$ ), the hydrogenation of $(\mathrm{CO})_{\mathrm{a}}$ exhibits a first-order dependence on the carbon monoxide surface coverage (Eq. (5)). A rate constant $k^{\prime}$ can thus be obtained for the hydrogenation of $(\mathrm{CO})_{\mathrm{a}}$. Table 2 presents a comparison of the transient hydrogenation rate of the $(\mathrm{CO})_{\mathrm{a}}$ surface species with the overall methane production rate measured at steady-state for different hydrogen partial pressures. These rates have to be compared at identical carbon monoxide surface coverage. Therefore the $(\mathrm{CO})_{\mathrm{a}}$ hydrogenation rate, $R_{\mathrm{CO}}$, is calculated according to Eq. (5) for a carbon monoxide surface coverage $\theta_{\mathrm{CO}}=0.51$ which corresponds to the value measured during the steady-state experiments:

$$
R_{\mathrm{CO}}=k^{\prime} N_{\mathrm{CO}}=k^{\prime} N_{\mathrm{CO}, \text { tot }} \theta_{\mathrm{CO}}
$$

where $N_{\mathrm{CO}, \text { tot }}$ is the maximum $(\mathrm{CO})_{\mathrm{a}}$ concentration on the catalyst, as determined by CO adsorption experiments. The $R_{\mathrm{CO}}$ values are either smaller or equal to the overall reaction rate $R_{\mathrm{CH}_{4}}$, calculated from the steady-state kinetic equation [6].

\subsection{Formation of the formate}

Hydrogen is required for the formation of the formate on the $2 \% \mathrm{Ru} / \mathrm{TiO}_{2}$ catalyst, since no infrared bands characteristic of this species are measured (Fig. $6 \mathrm{~b})$ on the catalyst exposed to carbon dioxide. Neither bands characteristic of adsorbed carbon monoxide and formate species are measured on a titania sample exposed to the carbon dioxide and hydrogen reaction mixture at $383 \mathrm{~K}$ (Fig. 6a). This shows that the presence of both hydrogen and ruthenium are required for the production of the carbon monoxide and formate surface species.

The influence of the ruthenium loading is shown in Fig. 7, by comparing the spectra recorded on the surface of $0.3 \%$ and $2 \% \mathrm{Ru} / \mathrm{TiO}_{2}$ catalysts after $60 \mathrm{~min}$ 


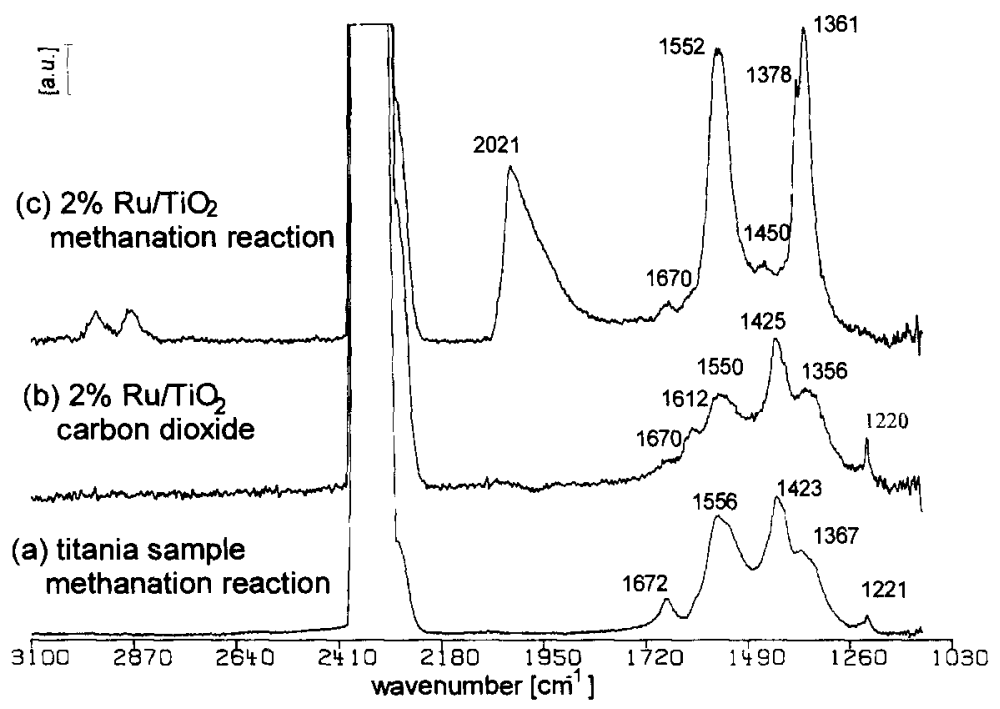

Fig. 6. (a) DRIFTS spectrum for the titania sample exposed for $45 \mathrm{~min}$ to the $10 \% \mathrm{CO}_{2}$ and $40 \% \mathrm{H}_{2}$ reaction mixture at $383 \mathrm{~K}$; (b) DRIFTS spectrum for $2 \% \mathrm{Ru} / \mathrm{TiO}_{2}$ exposed for $45 \mathrm{~min}$ to $10 \% \mathrm{CO}_{2}$ at $383 \mathrm{~K}$, a fixed-bed reactor containing $4 \mathrm{~g}$ of $2 \% \mathrm{Ru} / \mathrm{TiO}_{2}$ catalyst was placed upstream of the DRIFTS cell; (a) and (b) were measured in DRIFTS-reactor, $P_{\mathrm{H}_{2} \mathrm{O}}=0.8 \mathrm{mbar}$, feed $=50 \mathrm{Nml} / \mathrm{min}$, total pressure $=1.2 \mathrm{bar}$; (c) DRIFTS spectrum for $2 \% \mathrm{Ru} / \mathrm{TiO}_{2}$ during the steady-state carbon dioxide methanation reaction at $383 \mathrm{~K}$, see Fig. 1a.

of exposition to carbon dioxide and hydrogen at $383 \mathrm{~K}$. Bands characteristic of adsorbed carbon monoxide, carbonate, hydrogen carbonate and formate are observed on both catalysts. However, the vib $\mathrm{O}-\mathrm{C}-\mathrm{O}$ band $\left(1360 \mathrm{~cm}^{-1}\right)$ is more

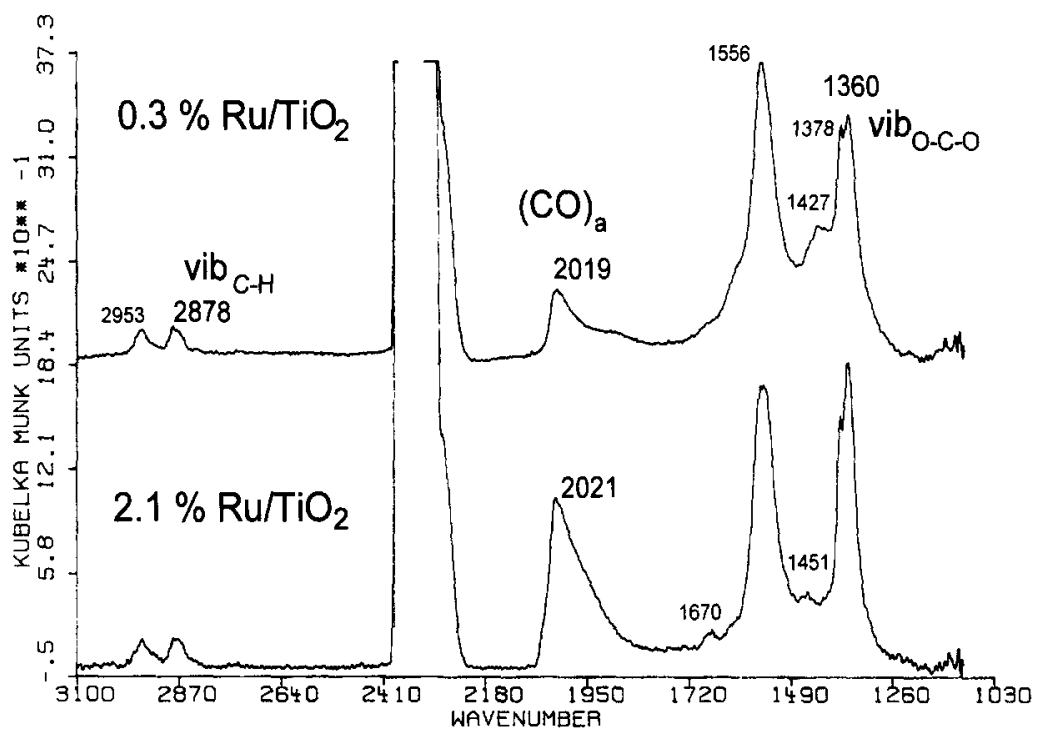

Fig. 7. DRIFTS spectra for $0.3 \% \mathrm{Ru} / \mathrm{TiO}_{2}$ and $2 \% \mathrm{Ru} / \mathrm{TiO}_{2}$ at $383 \mathrm{~K}$ after $60 \mathrm{~min}$ of reaction in a $10 \% \mathrm{CO}_{2}$ and $40 \% \mathrm{H}_{2}$ in $\mathrm{He} ; P_{\mathrm{H}_{2} \mathrm{O}}=0.8$ mbar; DRIFTS-reactor. 
intense for the catalyst of lower metal loading, when compared to the $(\mathrm{CO})_{\mathrm{a}}$ bands. This observation suggests that formate is bound to support sites.

An increase of the initial slope of production of formate is observed by a measure of the initial formation rate of the $\mathrm{vib}_{\mathrm{C}-\mathrm{H}}$ vibration, as the ruthenium loading is increased (Fig. 8). This observation shows that even though formate adsorption sites may be located on the support, the rate of formation of this species depends on the metal loading, which implies that the formate has to migrate from the metal, or the metal-support interface, to the support.

Prairie et al. [13] showed that the hydrogenation of gaseous carbon monoxide does not proceed on $3.8 \% \mathrm{Ru} / \mathrm{TiO}_{2}$ at $383 \mathrm{~K}$ because of physical blocking of hydrogenation sites generated by the strong adsorption of carbon monoxide. An experiment is performed in the DRIFTS-reactor where carbon monoxide is added to the reaction mixture to study how the saturation of the metal sites by $(\mathrm{CO})_{\mathrm{a}}$ affects the formation of adsorbed formate. The infrared spectrum recorded on the $2 \% \mathrm{Ru} / \mathrm{TiO}_{2}$ catalyst surface exposed for $40 \mathrm{~min}$ in $\mathrm{CO} / \mathrm{CO}_{2} / \mathrm{H}_{2}$ (3\%:10\%:40\%) at $383 \mathrm{~K}$ is given in Fig. 9. Gaseous carbon monoxide bands appear at 2174 and $2116 \mathrm{~cm}^{-1}$. Typical carbonate and hydrogen carbonate stretching vibrations appear at $1672,1549,1418$ and $1358 \mathrm{~cm}^{-1}$. However, the distinct 1361,1379 and $1556 \mathrm{~cm}^{-1}$ bands characteristic of adsorbed formate do not appear in this spectrum. This can be distinguished by comparing the height ratio between the vibrations at 1358 and $1418 \mathrm{~cm}^{-1}$ or the ratio between 1549 and $1418 \mathrm{~cm}^{-1}$, as illustrated in Fig. 11. Also methane is not detected in the effluent gases. Therefore the blocking of the metal sites by $(\mathrm{CO})_{\mathrm{a}}$ not only hinders the production of methane but also blocks the production of the surface formate ion.

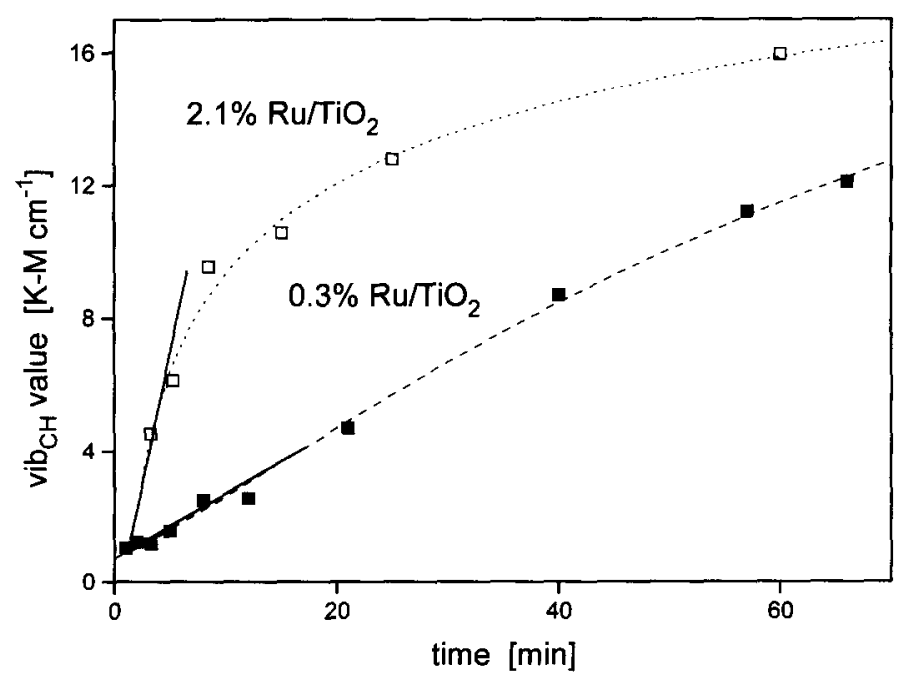

Fig. 8. Transient behavior of the $\mathrm{vib}_{\mathrm{C}-\mathrm{H}}$ value for $0.3 \% \mathrm{Ru} / \mathrm{TiO}_{2}$ and $2 \% \mathrm{Ru} / \mathrm{TiO}_{2}$ at $383 \mathrm{~K}$ after switching from $40 \% \mathrm{H}_{2}$ in $\mathrm{He}$ to $10 \% \mathrm{CO}_{2}$ and $40 \% \mathrm{H}_{2} ; P_{\mathrm{H}_{2} \mathrm{O}}=0.8$ mbar; DRIFTS-reactor. 


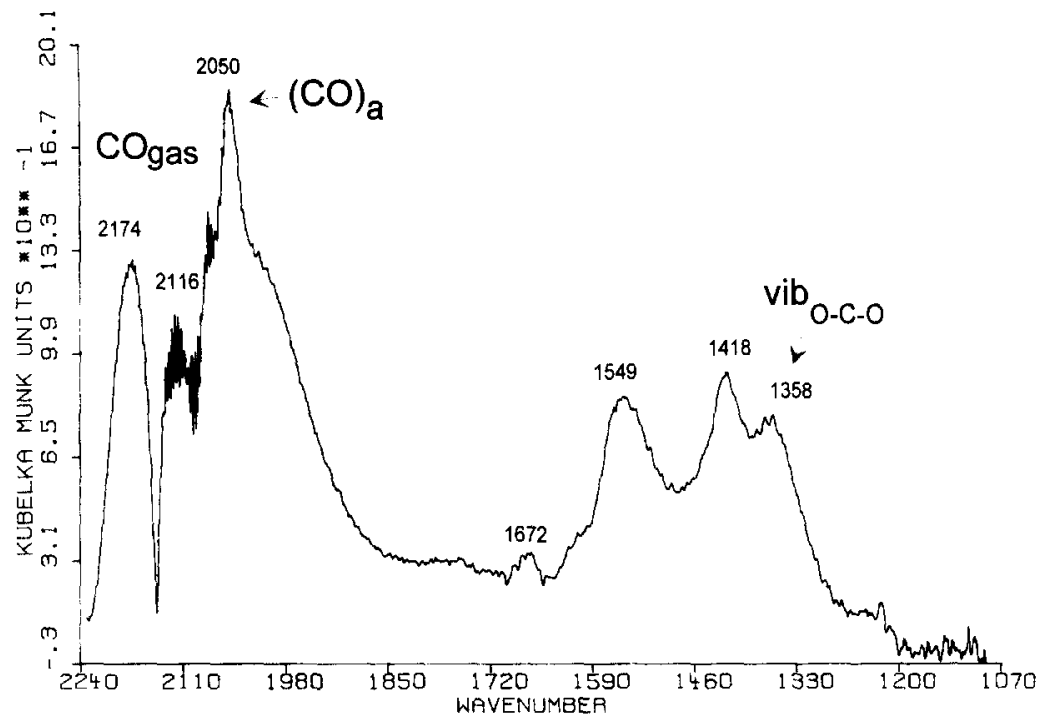

Fig. 9. DRIFTS spectra for $2 \% \mathrm{Ru} / \mathrm{TiO}_{2}$ at $383 \mathrm{~K}$ after 40 min of reaction in $3 \% \mathrm{CO}, 10 \% \mathrm{CO}_{2}$ and $40 \% \mathrm{H}_{2}$ in $\mathrm{He} ; P_{\mathrm{H}_{2} \mathrm{O}}=1.2 \mathrm{mbar}$; DRIFTS-reactor.

In the next step of this experiment the feed is switched back to a carbon monoxide-free reaction mixture. The response to this concentration switch is presented in Fig. 10. The $(\mathrm{CO})_{\mathrm{a}}$ infrared band intensity decreases to its steady-state carbon dioxide methanation value, while formate peaks slowly appear. Methane production suddenly increases at $t=2 \mathrm{~min}$. This increase is observed when the gas phase carbon monoxide concentration has decreased to a

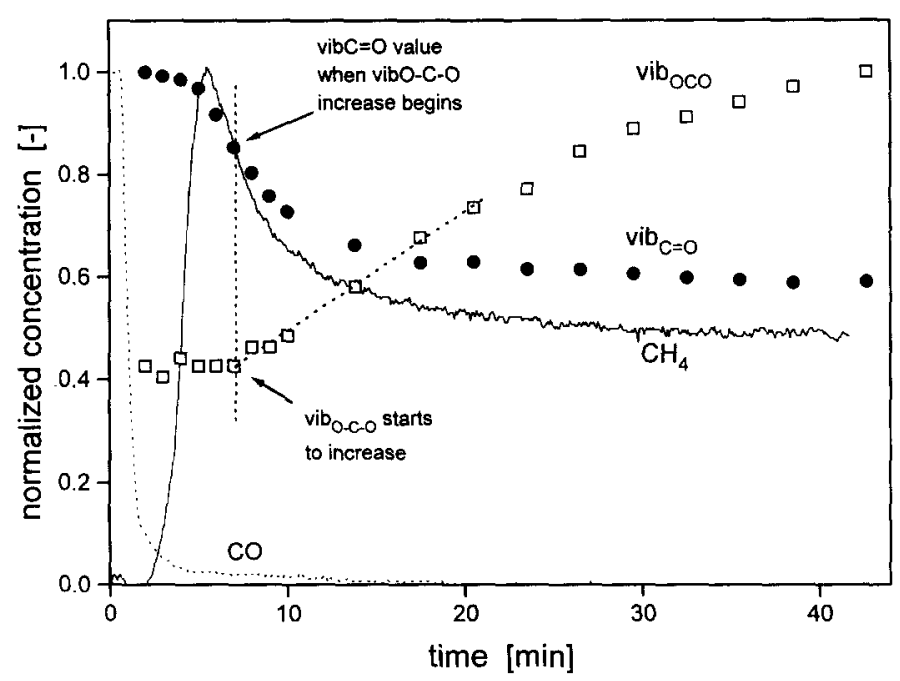

Fig. 10. Transient behavior of $\mathrm{CO}$, vib $\mathrm{C}=\mathrm{O}, \mathrm{vib}_{\mathrm{O}-\mathrm{C}-\mathrm{O}}$ and $\mathrm{CH}_{4}$ for $2 \% \mathrm{Ru} / \mathrm{TiO}_{2}$ at $383 \mathrm{~K}$ after switching from $3 \% \mathrm{CO}, 10 \% \mathrm{CO}_{2}$ and $40 \% \mathrm{H}_{2}$ in $\mathrm{He}$ to $10 \% \mathrm{CO}_{2}$ and $40 \% \mathrm{H}_{2} ; P_{\mathrm{H}_{2} \mathrm{O}}=1.2 \mathrm{mbar}$; DRIFTS-reactor. 
value corresponding to an equilibrium adsorbed carbon monoxide surface coverage slightly inferior to saturation. At that point, a few metal sites are freed and the hydrogenation reaction can take place. A sharp overshoot in the methane concentration is observed with a maximum corresponding to approximately twice the steady-state concentration. The methane concentration then decreases to its steady-state value. A concomitant decrease of $(\mathrm{CO})_{\mathrm{a}}$ and a slow increase of the $\mathrm{vib}_{\mathrm{O}-\mathrm{C}-\mathrm{O}}$ value are also observed. This increase of the $\mathrm{vib}_{\mathrm{O}-\mathrm{C}-\mathrm{O}}$ value, which corresponds to the formation of surface formate, is detected once the carbon monoxide coverage has reached approximately $85 \%$ of its saturation coverage. The higher methane production, as compared to the steady-state value, can be explained by the higher carbon monoxide surface coverage. Both values vary in a similar fashion. On the other hand, the formation of the formate has no visible effect on the production of methane, as this latter has almost decreased to its steady-state value while the surface concentration of formate is still increasing. These observations show that the formate ion cannot be reaction intermediate in the methane formation pathway. These observations are consistent with results reported by Solymosi et al. [5] who observed that the accumulation of the formate ion on a $\mathrm{Ru} / \mathrm{Al}_{2} \mathrm{O}_{3}$ catalyst at $473-523 \mathrm{~K}$ does not influence the rate of methanation. However, Solymosi et al. [28] also mention that, on $\mathrm{Rh} / \mathrm{Al}_{2} \mathrm{O}_{3}$ at $523 \mathrm{~K}$, the absorption bands of adsorbed formate reach their highest value already at the beginning of the reaction. Also Schild et al. ([29] and [30]) observe that formate is rapidly formed from carbon dioxide and hydrogen on $\mathrm{Pd} / \mathrm{ZrO}_{2}$ at $473 \mathrm{~K}$ while adsorbed carbon monoxide is formed later. Therefore the behavior of the formate species depends on the catalytic system studied. The $\mathrm{Ru} / \mathrm{TiO}_{2}$ catalyst exhibits a similar behavior as the $\mathrm{Ru} / \mathrm{Al}_{2} \mathrm{O}_{3}$ catalyst studied by Solymosi et al. [5] in the $473-523 \mathrm{~K}$ temperature range.

The possible interactions between carbonate/hydrogen carbonate and formate are examined by studying the response of the adsorbed species to a step-change from an initial carbon dioxide feed to a feed where hydrogen and carbon dioxide are present. In this experiment, the $2 \% \mathrm{Ru} / \mathrm{TiO}_{2}$ catalyst and the titania sample were first of all exposed for $40 \mathrm{~min}$ to a $10 \%$ carbon dioxide feed at $383 \mathrm{~K}$. In a second step, hydrogen was added to this feed. Spectra recorded on the catalyst and support surfaces after $40 \mathrm{~min}$ in carbon dioxide and $40 \mathrm{~min}$ in carbon dioxide/hydrogen are presented in Fig. 11. A net decrease of the $1428 \mathrm{~cm}^{-1}$ band, characteristic of adsorbed hydrogen carbonate, is observed for $2 \%$ $\mathrm{Ru} / \mathrm{TiO}_{2}$ after that hydrogen has been introduced in the system. Formate formation is observed in parallel. On the other hand no modification of the 1428 $\mathrm{cm}^{-1}$ band is observed for the titania sample where the formate ion is not formed. The evolution of $v \mathrm{bi}_{\mathrm{O}-\mathrm{C}-\mathrm{O}}$ and the $1428 \mathrm{~cm}^{-1}$ peak height as a function of time shows (Fig. 12) that the decrease of the hydrogen carbonate infrared band is much faster than the increase of the formate band. The 1428 $\mathrm{cm}^{-1}$ peak height reaches a steady-state value after $5 \mathrm{~min}$ while the $\mathrm{vib}_{\mathrm{O}-\mathrm{C}-\mathrm{O}}$ has not attained a steady-state value after $30 \mathrm{~min}$. Formate and hydrogen 


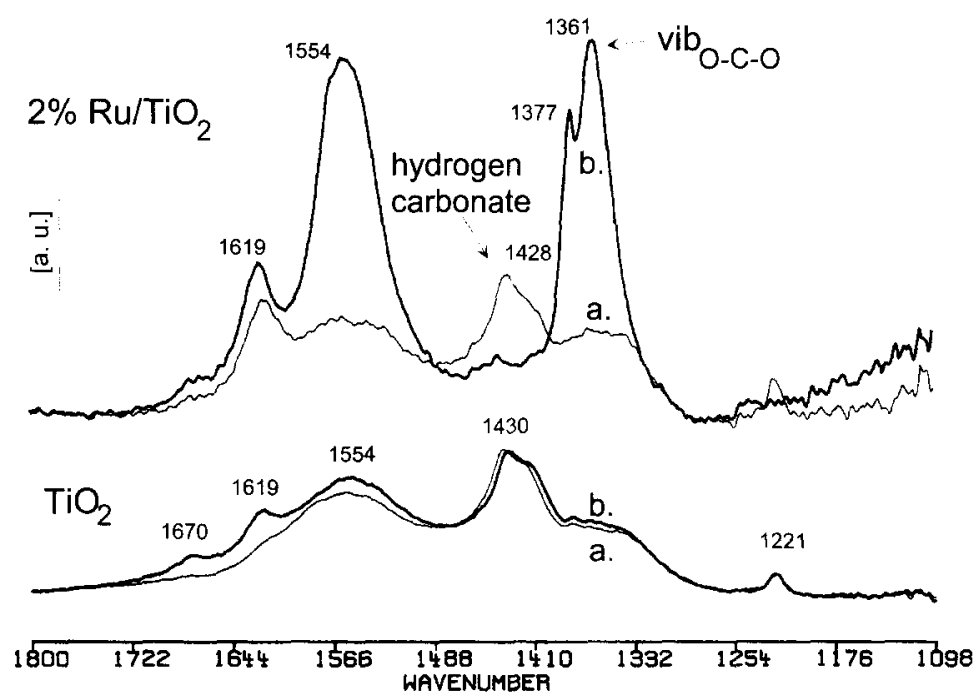

Fig. 11. DRIFTS spectra for $2 \% \mathrm{Ru} / \mathrm{TiO}_{2}$ and $\mathrm{TiO}_{2}$ at $383 \mathrm{~K}$ in: (a) $10 \% \mathrm{CO}_{2}$ in $\mathrm{He}$ for $40 \mathrm{~min}$, (b) $10 \%$ $\mathrm{CO}_{2}$ and $40 \% \mathrm{H}_{2}$ in $\mathrm{He}$ for $40 \mathrm{~min}$ following (a); $P_{\mathrm{H}_{2} \mathrm{O}}=0.8 \mathrm{mbar}$; DRIFTS-reactor.

carbonate ions are therefore not directly coupled. This observation is in contradiction with results presented by $\mathrm{Fu}$ et al. [31] and Amenomiya [32] who observed a concomitant decrease of the hydrogen carbonate infrared band with the increase of the formate peak on respectively $\mathrm{K}-\mathrm{Os} / \mathrm{Al}_{2} \mathrm{O}_{3}$ at $473 \mathrm{~K}$ in a carbon monoxide atmosphere and on $\mathrm{Al}_{2} \mathrm{O}_{3}$ at $573 \mathrm{~K}$ in a carbon dioxide and hydrogen atmosphere.

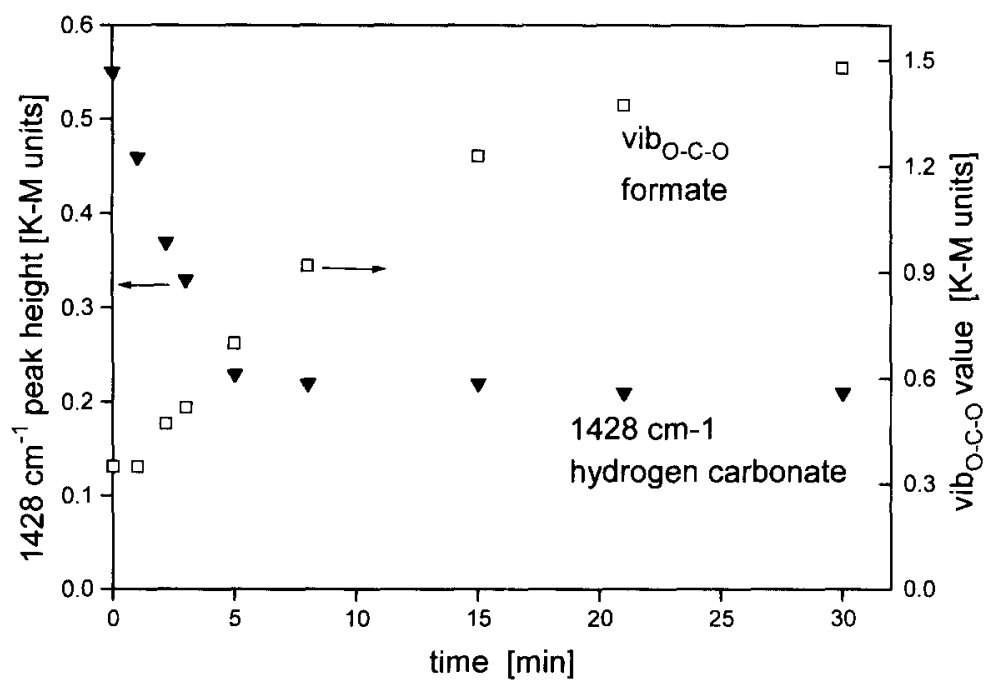

Fig. 12. Transient behavior of the vib $\mathrm{O}-\mathrm{C}-\mathrm{O}$ value and the $1428 \mathrm{~cm}^{-1}$ peak height for $2 \% \mathrm{Ru} / \mathrm{TiO}_{2}$ at $383 \mathrm{~K}$ after switching from $10 \% \mathrm{CO}_{2}$ in $\mathrm{He}$ to $10 \% \mathrm{CO}_{2}$ and $40 \% \mathrm{H}_{2} ; P_{\mathrm{H}_{2} \mathrm{O}}<0.8$ mbar (no water evaporator). 
The response of the $\mathrm{vib}_{\mathrm{O}-\mathrm{C}-\mathrm{O}}$ values to a step change in composition, from the reaction mixture to helium, is presented in Fig. 13 for $2 \% \mathrm{Ru} / \mathrm{TiO}_{2}$ at 383 $\mathrm{K}$ in the DRIFTS-reactor. The initial sharp decrease of vib ${ }_{\mathrm{O}-\mathrm{C}-\mathrm{O}}$ observed during the first $5 \mathrm{~min}$ of the experiment is attributed to the carbonate rather than to the formate component of $\mathrm{vib}_{\mathrm{O}-\mathrm{C}-\mathrm{O}}$. This is based on the following observations:

(a) during this initial 5-min period, the $\mathrm{C}-\mathrm{H}$ stretching vibration of formate is influenced to a much lesser extent than the $v^{-b_{-C}-O}$ value (Fig. 14). An additional $\mathrm{O}-\mathrm{C}-\mathrm{O}$ stretching vibration is therefore added to the $\mathrm{O}-\mathrm{C}-\mathrm{O}$ vibration of the formate species. After this 5 -min period, the variation of these two values becomes very similar, showing that the vib $\mathrm{O}-\mathrm{C}-\mathrm{O}_{\mathrm{O}}$ value is then only influenced by its formate component;

(b) the $\mathrm{O}-\mathrm{C}-\mathrm{O}$ stretching vibrations observed for the titania sample exposed to the reaction mixture are only due to carbonate and hydrogen carbonate species as formate is not formed on a titania sample (Fig. 6a). The response to a step-down experiment performed with titania shows a fast desorption of the carbonate and hydrogen carbonate species.

This initial decrease is followed by a much slower decrease of vib $\mathrm{O}_{\mathrm{C}-\mathrm{O}}$ which is attributed to the desorption of the formate ion. Formate is therefore more strongly bound to the surface of the $2 \% \mathrm{Ru} / \mathrm{TiO}_{2}$ catalyst than the carbonate and hydrogen carbonate ions. A slow desorption is observed for the formate in helium at $383 \mathrm{~K}$.

An identical initial sharp decrease of vib $\mathrm{O}-\mathrm{C}-\mathrm{O}_{\mathrm{O}}$ is observed for a step change in composition to hydrogen. This decrease, observed during the first $5 \mathrm{~min}$ of

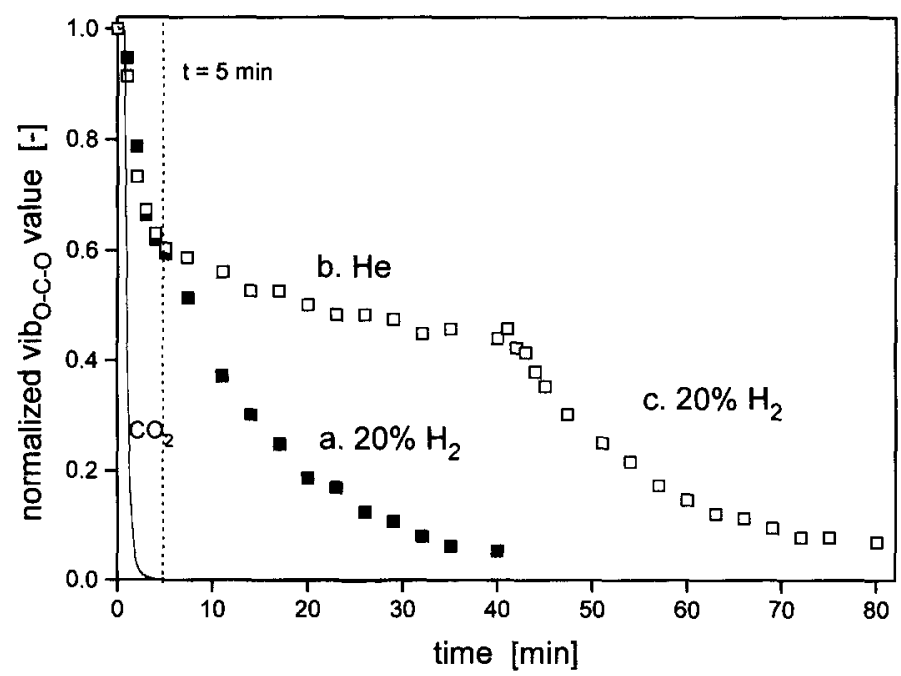

Fig. 13. Transient behavior of the normalized $v^{2} b_{\mathrm{O}_{-} \mathrm{O}}$ value for $2 \% \mathrm{Ru} / \mathrm{TiO}_{2}$ at $383 \mathrm{~K}$ after switching from $10 \% \mathrm{CO}_{2}$ and $20 \% \mathrm{H}_{2}$ in $\mathrm{He}$ to: (a) $20 \% \mathrm{H}_{2}$, (b) $100 \% \mathrm{He}$, (c) $20 \% \mathrm{H}_{2}$ following (b); $P_{\mathrm{H}_{2} \mathrm{O}}=2.6 \mathrm{mbar}$; DRIFTS-reactor. 


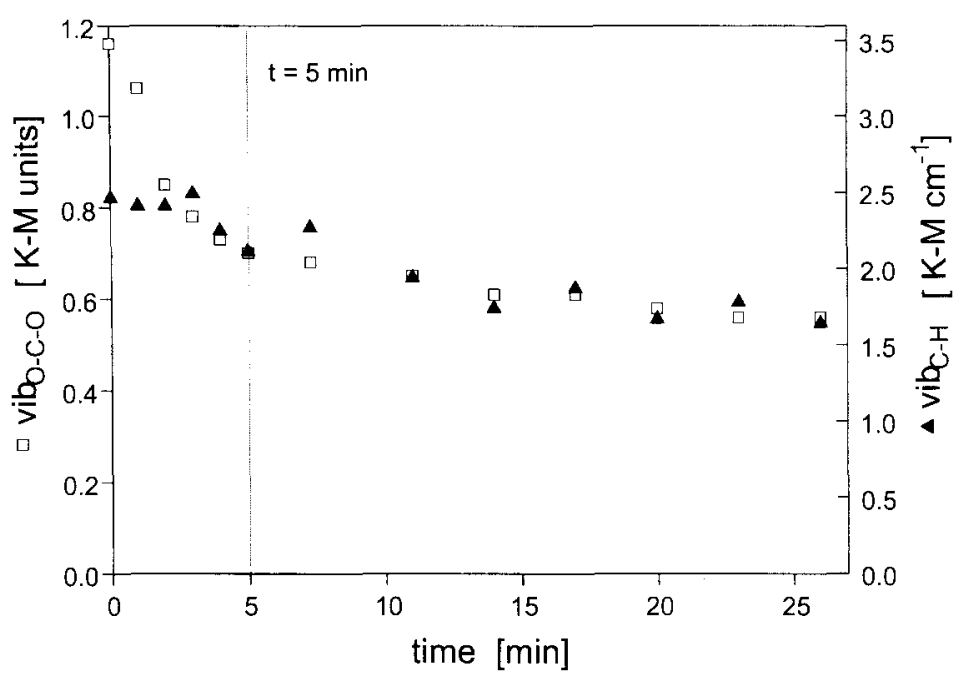

Fig. 14. Transient behavior of vib $\mathrm{O}-\mathrm{C}-\mathrm{O}$ and $\mathrm{vib}_{\mathrm{C}-\mathrm{H}}$ values for $2 \% \mathrm{Ru} / \mathrm{TiO}_{2}$ at $383 \mathrm{~K}$ after switching from $10 \% \mathrm{CO}_{2}$ and $20 \% \mathrm{H}_{2}$ in He to $100 \% \mathrm{He} ; P_{\mathrm{H}_{2} \mathrm{O}}=2.6 \mathrm{mbar}$.

the experiment, is associated to the fast desorption of the carbonate and hydrogen carbonate species. Hydrogen does not affect this desorption. However, a different response of $\mathrm{vib}_{\mathrm{O}-\mathrm{C}-\mathrm{O}}$ is observed after the 5 -min period, with a much faster decrease of the vib $\mathrm{O}_{-\mathrm{C}-\mathrm{O}}$ value observed in the presence of hydrogen. The $\mathrm{vib}_{\mathrm{O}-\mathrm{C}-\mathrm{O}}$ value is representative of the formate ion in this latter period and this experiment shows that the formate species is reactive in hydrogen.

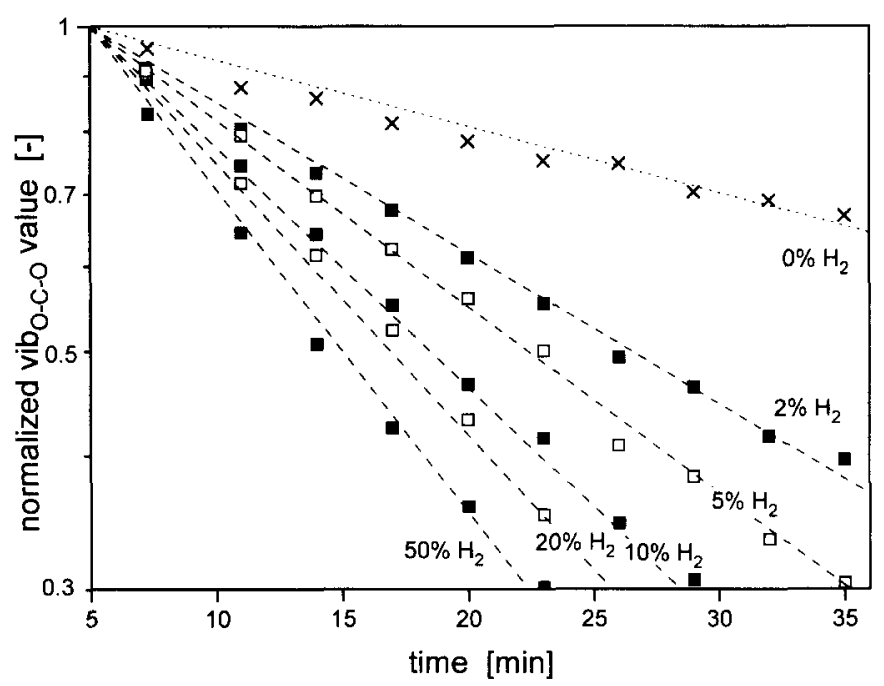

Fig. 15. Semi-log plot of the normalized vib $\mathrm{O}-\mathrm{C}-\mathrm{O}$ values vs. time for $2 \% \mathrm{Ru} / \mathrm{TiO}_{2}$ at $383 \mathrm{~K}$ after switching from $20 \% \mathrm{H}_{2}$ and $10 \% \mathrm{CO}_{2}$ in $\mathrm{He}$ to $x \% \mathrm{H}_{2}$, with $x=0,2,5,10,20$ and $50 ; P_{\mathrm{H}_{2} \mathrm{O}}=1.6 \mathrm{mbar}$; DRIFTS-reactor. 
Fig. 15 shows the time dependency of $\mathrm{vib}_{\mathrm{O}-\mathrm{C}-\mathrm{O}}$ for different hydrogen molar fractions. $\mathrm{Vib}_{\mathrm{O}-\mathrm{C}-\mathrm{O}}$ data were normalized against the value recorded $5 \mathrm{~min}$ after the switch, in order to follow selectively the formate component of vib $\mathrm{O}-\mathrm{C}-\mathrm{O}_{\mathrm{O}}$ It is estimated that carbonate species have sufficiently desorbed after $5 \mathrm{~min}$ to be negligible compared to the formate component of vib $\mathrm{O}-\mathrm{C}-\mathrm{O}_{\mathrm{O}}$. Good linearity is obtained suggesting that formate hydrogenation depends in the first-order on the formate surface coverage. Methane was evolved during these experiments, but it is not known how much was due to the direct reaction of formate and how much is formed through carbon monoxide, since whenever formate is present, adsorbed carbon monoxide is also seen. The first-order dependence on the formate surface coverage is consistent with results presented by $\mathrm{Fu}$ et al. [31] on $\mathrm{K}-\mathrm{Os} / \mathrm{Al}_{2} \mathrm{O}_{3}$, Amenomiya [32] on $\mathrm{Al}_{2} \mathrm{O}_{3}$, and Shido et al. [18,33] on $\mathrm{MgO}$ and $\mathrm{ZnO}$ catalysts. Divergent views are, however, found concerning the effect of the hydrogen partial pressure on the formate consumption rate. Amenomiya [32] measures no effect of hydrogen on the formate decomposition rate on $\mathrm{Al}_{2} \mathrm{O}_{3}$ at $676 \mathrm{~K}$. Prairie et al. [13] even measure a inhibiting effect of hydrogen on the formate decomposition on $3.8 \% \mathrm{Ru} / \mathrm{TiO}_{2}$ at $383 \mathrm{~K}$, although hydrogen is required for formate removal. On the other hand, Shido et al. [33] show a promotion of the formate decomposition rate on $\mathrm{ZnO}$ by the coexistence of hydrogen, as compared with that in vacuum.

Step-down hydrogenation experiments were also performed at different water partial pressures or temperatures to measure the effect of these parameters on the hydrogenation of $\left(\mathrm{HCOO}^{-}\right)_{\mathrm{a}}$. The removal of adsorbed formate is observed to be enhanced by water in the presence of hydrogen and an activation energy of $E_{\mathrm{a}}=34 \pm 12 \mathrm{~kJ} / \mathrm{mol}$ is measured between 373 and $403 \mathrm{~K}$.

\subsection{Effect of water on the adsorbed species}

The effect of the concentration of water on the adsorbed species at steady-state during the carbon dioxide methanation reaction is shown in Fig. 16, where water has a marked influence on the formate steady-state coverage while adsorbed carbon monoxide is influenced to a much lesser extent. The concentration of both species decreases as water partial pressure increases. This observation has to be added to the fact that the overall methanation reaction rate has been observed to be inhibited by water.

\subsection{Reaction mechanism}

DRIFTS experiments have been performed where the catalyst was exposed to a $10 \% \mathrm{CO}_{2}$ in $\mathrm{He}$ stream at $383 \mathrm{~K}$ in order to determine if the dissociative adsorption of $\mathrm{CO}_{2}$ was responsible for the formation of the ( $\left.\mathrm{CO}\right)_{\text {a }}$ surface intermediate. No accumulation of adsorbed carbon monoxide was measured (Fig. 6b). This experiment is very sensitive to trace impurities in the $\mathrm{CO}_{2}$ gas, 


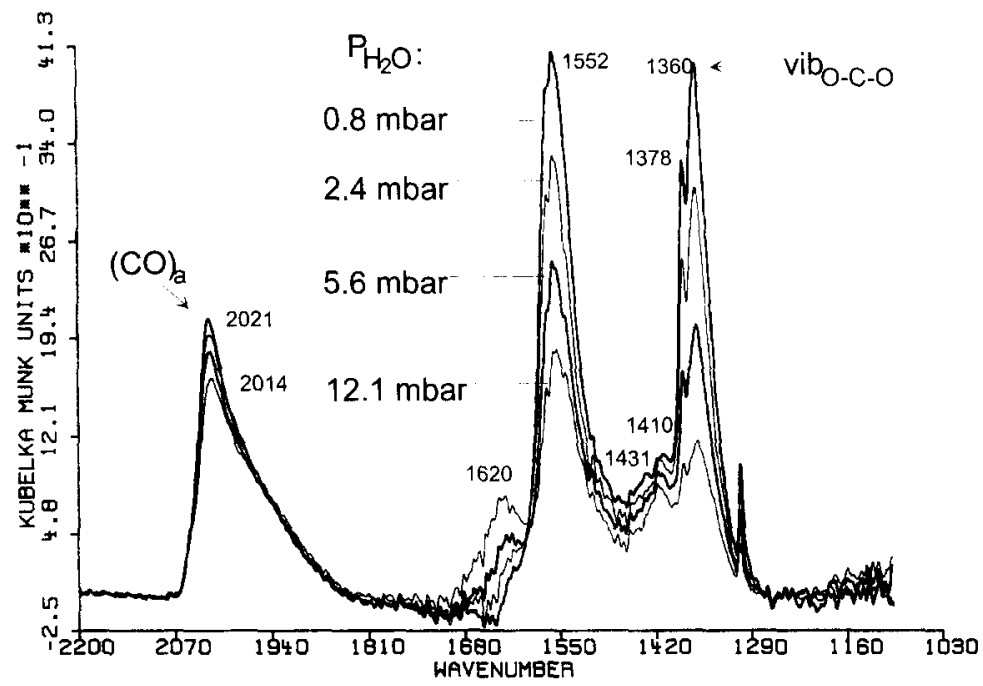

Fig. 16. DRIFTS spectra for $2 \% \mathrm{Ru} / \mathrm{TiO}_{2}$ at $383 \mathrm{~K}$ after 60 min of reaction in $10 \% \mathrm{CO}_{2}$ and $40 \% \mathrm{H}_{2}$ in $\mathrm{He}$ for water partial pressures of $P_{\mathrm{H}_{2} \mathrm{O}}=0.8,2.4,5.6$ and $12.1 \mathrm{mbar}$. This experiment was performed in the DRIFTS-recycle-reactor; $4 \mathrm{~g}$ of $2 \% \mathrm{Ru} / \mathrm{TiO}_{2}$ catalyst, recycle ratio $=70$, feed $=50 \mathrm{Nml} / \mathrm{min}$.

which have been removed using a fixed bed containing $4 \mathrm{~g}$ of $2 \% \mathrm{Ru} / \mathrm{TiO}_{2}$ placed upstream of the DRIFTS cell. The carbon dioxide dissociation mechanism is consequently rejected for this catalyst at $383 \mathrm{~K}$. A similar conclusion is reached for a $3.8 \% \mathrm{Ru} / \mathrm{TiO}_{2}$ catalyst by Highfield et al. [34]. Since carbon monoxide is not formed by the dissociative adsorption of carbon dioxide, the question arises whether it is formed by the decomposition of the adsorbed formate species.

DRIFTS step-up experiments showed that a steady-state value for the formate species is only attained after $40 \mathrm{~min}$, while steady-state values for adsorbed carbon monoxide and methane are already reached after $10 \mathrm{~min}$ of reaction. Hence, adsorbed formate cannot be included as a direct reaction intermediate in the methane formation pathway. As a result the formate species is located on a parallel route.

Variations of the concentration of water in the system resulted in comparable variations of $\mathrm{vib}_{\mathrm{O}-\mathrm{C}-\mathrm{O}}$ and $R_{\mathrm{CH}_{4}}$. It was proposed that adsorbed formate is formed through a surface intermediate which is placed in the methane reaction pathway and whose concentration is controlled by water. The steady-state methane and $\mathrm{vib}_{\mathrm{O}-\mathrm{C}-\mathrm{O}}$ values can therefore exhibit a similar behavior towards water although the steady-state of each species is not attained at the same time.

$$
\begin{aligned}
& \mathrm{CO}_{2} \Leftrightarrow \frac{\mathrm{X}}{\mathbb{1}} \Leftrightarrow(\mathrm{CO})_{2} \Leftrightarrow \mathrm{CH}_{4} \\
& \left(\mathrm{HCOO}^{-}\right) \text {. } \\
& \text { Scheme } 1 .
\end{aligned}
$$




$$
\mathrm{CO}_{2} \Leftrightarrow \underset{\substack{\prod \\\left(\mathrm{HCOO}^{-}\right)_{\mathrm{S}}}}{\left(\mathrm{HCOO}^{-}\right)_{\mathrm{I}}} \Leftrightarrow \quad(\mathrm{CO})_{\mathrm{M}} \Leftrightarrow \mathrm{CH}_{4}
$$

Scheme 2 .

Scheme 1 complies with this observation, if it is assumed that water controls the steady-state concentration of the $X$ surface intermediate.

However, the formate species is not inactive. Transient step-down experiments showed that a faster decrease of the vib ${ }_{\mathrm{O}-\mathrm{C}-\mathrm{O}}$ value is observed after 5 min in hydrogen than in $100 \%$ helium (Fig. 13). The vib ${ }_{\mathrm{O}-\mathrm{C}-\mathrm{O}}$ value is representative of the formate ion in this latter period and this experiment shows that the formate ion is reactive in hydrogen.

We are therefore faced with the following paradox. The increase of the concentration of adsorbed formate does not modify the overall methane formation [8] but formate reacts with hydrogen following first order kinetics. A surface diffusion process is proposed to reconcile these data.

Solymosi et al. [5,28,35] propose that the formate ion is formed on the metal but migrates rapidly on to the support during the carbon dioxide methanation reaction on supported $\mathrm{Ru}, \mathrm{Rh}$ and $\mathrm{Pd}$ catalysts. Therefore, the formate species detected by infrared spectroscopy corresponds to a species adsorbed on to the support.

The following observations show that this latter view applies to our catalytic system: (a) the bands assigned to adsorbed formate are identical in the spectra recorded on titania exposed to formic acid and on $2 \% \mathrm{Ru} / \mathrm{TiO}_{2}$ exposed to carbon dioxide and hydrogen at $383 \mathrm{~K}$; (b) the steady-state $\mathrm{vib}_{\mathrm{O}-\mathrm{C}-\mathrm{O}}$ value, corresponding to the formate formed during the carbon dioxide methanation reaction, is not directly proportional to the metal loading of the catalyst (Fig. 7); (c) DRIFTS step-up experiments show that the formate coverage increases without perturbing the metal-adsorbed carbon monoxide coverage.

However, the following observations also show that the ruthenium metal plays an active role in the formation of the formate species: (a) infrared bands corresponding to the formate ion are not detected in the spectrum recorded on titania exposed to carbon dioxide and hydrogen at $383 \mathrm{~K}$ (Fig. 6a); (b) DRIFTS step-up experiments show an enhancement of the initial slope of formation of the formate species when the ruthenium loading is increased from $0.3 \%$ to $2 \%$ (Fig. 8); (d) the development of adsorbed formate is not observed if carbon monoxide is added to the reaction mixture (Fig. 9).

A scheme where formate is formed at the metal-support interface (I) and subsequently diffuses on to the support (S) is proposed (Scheme 2).

$$
\mathrm{CO}_{2}+\left(\mathrm{OH}^{-}\right)_{\mathrm{S}} \leftrightarrow\left(\mathrm{HCO}_{3}^{-}\right)_{\mathrm{S}} \stackrel{+2}{\leftrightarrow} \leftrightarrow(\mathrm{H})_{\mathrm{M}}\left(\mathrm{HCOO}^{-}\right)_{\mathrm{I}}+\mathrm{H}_{2} \mathrm{O}
$$

Scheme 3. 


$$
\begin{aligned}
& \mathrm{CO}_{2} \\
& \text { II } \\
& \left(\mathrm{HCOO}^{-}\right)_{\mathrm{s}} \stackrel{\text { net flow }}{\leftarrow}\left(\mathrm{HCOO}^{-}\right)_{1} \rightarrow(\mathrm{CO})_{\mathrm{M}} \Rightarrow \mathrm{CH}_{4}
\end{aligned}
$$

It is proposed that the interfacial formate species, $\left(\mathrm{HCOO}^{-}\right)_{\mathrm{I}}$, is rapidly formed during the step-up experiment. It can be formed for example by the reduction of a support-bound hydrogen carbonate species with metal adsorbed hydrogen at the interface (Scheme 3).

This possibility is consistent with the rapid formation of the hydrogen carbonate species observed during the step-up experiments, as well as with the rapid decrease of the hydrogen carbonate infrared bands observed when hydrogen is added to the carbon dioxide feed.

The interfacial formate species is in equilibrium and for this reason its concentration is not perturbed by the subsequent surface diffusion of the formate species to the support (Scheme 4).

Therefore a steady-state value for the coverage of the support-bound formate species can be attained during the step-up experiment after that adsorbed carbon monoxide coverage and methane production have reached their own steady-state. No infrared bands could be assigned to the interfacial formate species. The following suggestions are advanced to explain this fact: (a) the bands characteristic of interfacial formate might escape detection due to the small amount of these species; (b) they might be hidden by more intense infrared bands characteristic of the support-bound formate and carbonate species; (c) they might not be distinguished from the bands characteristic of the titania bound formate in a similar fashion as the $\mathrm{ZnO}-\mathrm{Cu}$ interfacial formate proposed by Millar et al. [36].

During step-down experiments, the gaseous carbon source $\left(\mathrm{CO}_{2}\right)$ is cut off. As a result, the equilibrium between the interfacial formate and carbon dioxide (or hydrogen carbonate) cannot control the concentration of this species. The net result is a decrease of its concentration as carbon monoxide is hydrogenated. This generates a concentration gradient between the support and interfacial formate and the result is a migration of the former species towards the interface (Scheme 5).

The observations that the increase of the concentration of adsorbed formate does not modify the overall methane formation while formate reacts with hydrogen following first order kinetics can therefore be explained if surface diffusion is included in the reaction scheme. The low activation energy for the formate desorption measured during the step-down experiments is consistent

$$
\left(\mathrm{HCOO}^{-}\right)_{\mathrm{s}} \stackrel{\text { nof low }}{\rightarrow}\left(\mathrm{HCOO}^{-}\right)_{1} \rightarrow(\mathrm{CO})_{\mathrm{M}} \Rightarrow \mathrm{CH}_{4}
$$


with the hypotheses of an influence of diffusion in the formate hydrogenation process.

\section{Conclusions}

Based on in-situ transient measurements using DRIFT infrared spectroscopy, a reaction mechanism is proposed for the carbon dioxide methanation reaction on $2 \% \mathrm{Ru} / \mathrm{TiO}_{2}$ at $383 \mathrm{~K}$, involving the existence of a precursor for adsorbed carbon monoxide, a reaction intermediate in the pathway to methane, while formate is a side-product adsorbed on the support. It is further suggested that this surface intermediate corresponds to a formate adsorbed at the metal-support interface, and that the formate infrared bands measured correspond to the formate species that has diffused from the interface to the support. The hydrogenation of the adsorbed carbon monoxide is presented in a lumped form involving 6 adsorbed hydrogens, which is obviously not an elementary reaction, but the different hydrogenation steps cannot be distinguished by infrared spectroscopy (Scheme 6). A pathway involving hydrogen carbonate (Scheme 3) is presented for the formation of the interfacial formate because DRIFTS experiments have shown that this species is formed on the support during the reaction and that its transient response is consistent with the response of a carbon monoxide precursor.

The inhibiting effect of water on the formation of carbon monoxide is explained by the reaction of water with interfacial formate to form hydrogen carbonate. This reaction is part of the equilibrium which controls the steady-state concentration of the interfacial formate species and consequently the steady-state concentration of the formate adsorbed on the support. The promoting effect of hydrogen (Fig. 6) on the formation of adsorbed carbon monoxide is explained by the fact that metal-adsorbed hydrogen is required to reduce the hydrogen carbonate. The increase of the metal loading increases the concentration of interfacial sites on the catalyst and therefore results in a faster initial diffusion

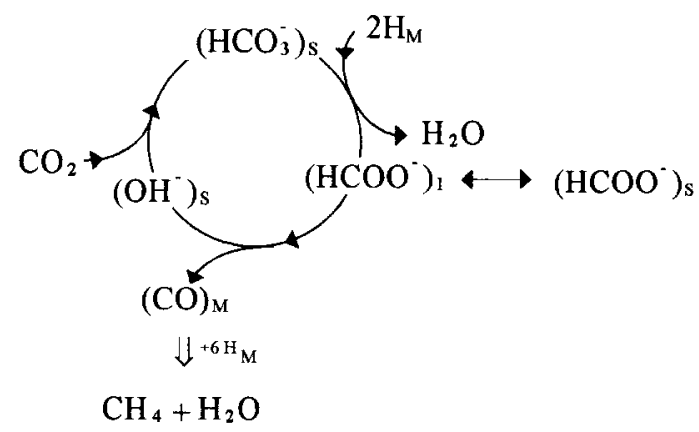

Scheme 6. 
rate of the formate to the support (Fig. 8). Physical blocking of the metal by adsorbed carbon monoxide either blocks the interfacial sites or inhibits the hydrogen dissociation on the metal. The interfacial formate formation is thus inhibited which results in the observation that neither methane nor support-bound formate are formed (Fig. 10). The main steady-state and transient observations presented are therefore taken into account by this reaction scheme.

Regarding the role of the formate species in the overall reaction it is concluded, similarly as proposed by Solymosi et al. [5], that the formate infrared bands measured by DRIFTS correspond to a side-product adsorbed on the support. However, it is suggested that the observation of such a species is indicative of a formate species adsorbed at the metal-support interface, which is regarded as the precursor of carbon monoxide.

\section{Acknowledgements}

We are grateful to the Swiss National Science Foundation for financial support.

\section{References}

[1] A. Renken. in Yu.Sh. Matros (Editor), Unsteady State Processes in Catalysis, VSP, Utrecht, 1990, p. 183.

[2] K. Tamaru. Dynamic relaxation methods, in J.R. Anderson and M. Boudard (Editors), Heterogeneous Catalysis, Catalysis: Science and Technology, vol. 9, Springer Verlag, 1991, p. 88.

[3] M.A. Henderson and S.D. Worley, An infrared study of the hydrogenation of carbon dioxide on supported rhodium catalysts, J. Phys. Chem., 89 (1985) 1417-1423.

[4] A. Erdöhelyi, M. Pasztor and F. Solymosi, Catalytic hydrogenation of $\mathrm{CO}_{2}$ over supported palladium, J. Catal., 98 (1986) 166-177.

[5] F. Solymosi, A. Erdöhelyi and M. Kocsis, Methanation of $\mathrm{CO}_{2}$ on supported Ru catalysts, J. Chem. Soc., Faraday Trans. 1, 77 (1981) 1003-1012.

[6] M. Marwood, F. Van Vyve, R. Doepper and A. Renken, Periodic operation applied to the kinetic study of $\mathrm{CO}_{2}$ methanation, Catal. Today, 20 (1994) 437-448.

[7] M. Marwood, R. Doepper, M. Prairie and A. Renken, Transient DRIFT spectroscopy for the determination of the surface reaction kinetics of $\mathrm{CO}_{2}$ methanation, Chem. Eng. Sci., 49(24A) (1995) 4801-4809.

[8] M. Marwood, Kinetic studies of the catalytic carbon dioxide methanation under transient conditions In-situ surface and gas phase analysis, PhD thesis, Swiss Federal Institute of Technology, Switzerland. 1994.

[9] N.W. Cant and A.T. Bell, Studies of carbon monoxide hydrogenation over ruthenium using transient response techniques. J. Catal., 73 (1982) 257-271.

[10] N.M. Gupta, V.S. Kamble, R.M. Iyer, K.R. Thampi and M. Grätzel, The transient species formed over $\mathrm{Ru}-\mathrm{RuO}_{\mathrm{r}} / \mathrm{TiO}_{2}$ catalyst in the $\mathrm{CO}$ and $\mathrm{CO}+\mathrm{H}_{2}$ interaction: FTIR spectroscopic study, J. Catal., 137 (1992) 473-486.

[11] N. Sheppard and T.T. Nguyen, The vibrational spectra of carbon monoxide chemisorbed on the surfaces of metal catalysts - a suggested scheme of interpretation, in R.J.H. Clark and R.E. Hester (Editors), Advances in Infrared and Raman Spectroscopy, Vol. 5, and references therein, Heydn, 1978, pp. 67-148.

[12] R.A. Dalla Betta and M. Shellef, Heterogeneous methanation: in situ infrared spectroscopic study of $\mathrm{Rh} / \mathrm{Al}_{2} \mathrm{O}_{3}$ during hydrogenation of $\mathrm{CO}$, J. Catal., 73 (1977) 257-271.

[13] M.R. Prairie, J.G. Highfield and A. Renken, Diffuse-reflectance FTIR spectroscopy for kinetic and 
mechanistic studies of $\mathrm{CO}_{2}$ hydrogenation in a continuous recycle reactor, Chem. Eng. Sci., 46(1) (1991) $113-121$.

[14] M.R. Prairie, J.G. Highfield, A.K. Renken R. Thampi and M. Grätzel, A Fourier transform infrared spectroscopic study of $\mathrm{CO}_{2}$ methanation on supported ruthenium, J. Catal., 129 (1991) 130-144.

[15] J.G. Highfield, M. Prairie and A. Renken, In-situ DRIFT spectroscopy in a continuous recycle reactor: a versatile tool for catalytic process research, Catal. Today, 9 (1991) 39-46.

[16] N.M. Gupta, V.S. Kamble, V.B. Kartha, R.M. Iyer, K.R. Thampi and M. Grätzel, FTIR spectroscopic study of the interaction of $\mathrm{CO}_{2}$ and $\mathrm{CO}_{2}+\mathrm{H}_{2}$ over partially oxidized $\mathrm{Ru} / \mathrm{TiO}$ 2 catalyst, J. Catal., 146 (1994) 173-184.

[17] G. Busca, J. Lamotte, J-C. Lavalley and V. Lorenzelli, FT-IR study of the adsorption and transformation of formaldehyde on oxide surfaces, J. Am. Chem. Soc., 109 (1987) 5197-5202.

[18] T. Shido, K. Asakura and Y. Iwasawa, Reactant-promoted reaction mechanism for catalytic water-gas shift reaction on MgO, J. Catal., 122 (1990) 55-67.

[19] C. Morterra, A. Chiorino, F. Boccuzzi and E. Fisicaro, A spectroscopic study of anatase properties: 4. The adsorption of carbon dioxide, Z. Phys. Chem. Neue Folge, 124 (1981) 211-222.

[20] P. Jackson and G.D. Parfitt, Infra-red study of the surface properties of rutile: Deuterium exchange, carbon dioxide and But-1-ene adsorption, J. Chem. Soc., Faraday Trans. 1, 67 (1971) 896-906.

[21] P.D. Reed, C.M. Comrie and R.M. Lambert, Chemisorption, surface structural chemistry, and electron impact properties of carbon monoxide on Ru(101), Surf. Sci., 59 (1976) 33-45.

[22] J.C. Fuggle, E. Umbach, P. Feulner and D. Menzel, Electron induced dissociation of $\mathrm{CO}$ on Ru(001), Surf. Sci., 64 (1977) 69-84.

[23] D.W. Goodman, T.E. Madey, M. Ono and J.T. Yates Jr., Interaction of hydrogen, carbon monoxide, and formaldehyde with ruthenium, J. Catal., 50 (1977) 279-290.

[24] H. Pfnür, P. Feulner, H.A. Englehardt and D. Menzel, An example of « fast $\gg$ desorption: anomalously high pre-exponentials for CO desorption from Ru (001), Chem. Phys. Lett., 59 (1978) 481-485.

[25] F. Solymosi, I. Tombacz and M. Kocsis, Hydrogenation of CO on supported Rh catalysts, J. Catal., 75 (1982) 78-93.

[26] T. Mori, H. Masuda, H. Imai, A. Miyamoto, S. Baba and Y. Murakami, Kinetics, isotope effects, and mechanism for the hydrogenation of carbon monoxide on supported nickel catalysts, J. Phys. Chem., 86 (1982) 2753-2760.

[27] F.M. Hoffmann, IRAS of adsorbed molecules, Surf. Sci. Rep., 3 (1983) 132-192.

[28] F. Solymosi, A. Erdöhelyi and T. Bansagi, Methanation of $\mathrm{CO}_{2}$ on supported Rhodium catalyst, J. Catal., 68 (1981) 371-382.

[29] C. Schild, A. Wokaun and A. Baiker, On the mechanism of $\mathrm{CO}$ and $\mathrm{CO}_{2}$ hydrogenation reactions on zirconia-supported catalysts: a diffuse reflectance FTIR study, Part I. Identification of surface species and methanation reactions on palladium/zirconia catalysts, J. Mol. Catal., 63 (1990) 223-242.

[30] C. Schild, A. Wokaun and A. Baiker, Surface species in $\mathrm{CO}_{2}$ methanation over amorphous palladium/zirconia catalysts, J. Mol. Catal., 69 (1991) 347-357.

[31] Y. Fu, L. Kraus and H. Knözinger, Formation and reactivities of formate species on a potassium-modified osmium/alumina catalyst: an infrared spectroscopic study, J. Mol. Catal., 52 (1989) 113-127.

[32] Y. Amenomiya, Active sites of solid acidic catalysts, III. Infrared study of the water gas conversion reaction on alumina. J. Catal., 57 (1979) 64-71.

[33] T. Shido and Y. Iwasawa, The effect of coadsorbates in reverse water-gas shift reaction on $\mathrm{ZnO}$, in relation to reactant-promoted mechanism, J. Catal., 140 (1993) 575-584.

[34] J.G. Highfield, P.K. Ruterana, R. Thampi and M. Graetzel, Catalyst characterization and in situ FTIR studies of carbon dioxide methanation over ruthenium supported on titania, Stud. Surf. Sci. Catal., 48 (1989) 469-479.

[35] F. Solymosi, A. Erdöhelyi and M. Lancz, Surface interaction between $\mathrm{H}_{2}$ and $\mathrm{CO}_{2}$ over Palladium on various supports, J. Catal., 95 (1985) 567-577.

[36] G.J. Millar, C.H. Rochester, S. Baily and K.C. Waugh, A combined temperature-programmed reaction spectroscopy and Fourrier-transform infrared spectroscopy study of $\mathrm{CO}_{2}-\mathrm{H}_{2}$ and $\mathrm{CO}-\mathrm{CO}_{2}-\mathrm{H}_{2}$ interactions with model $\mathrm{ZnO} / \mathrm{SiO}_{2}, \mathrm{Cu} / \mathrm{SiO}_{2}$ and $\mathrm{Cu} / \mathrm{ZnO} / \mathrm{SiO}_{2}$ methanol-synthesis catalysts, J. Chem. Soc. Faraday Trans., 88(14) (1992) 2085-2093. 